\title{
Air Pollution and Its Effects in the Respiratory System
}

\author{
Fortoul, T.I. et al.* \\ Departamento de Biologia Celular y Tisular, Facultad de Medicina \\ Universidad Nacional Autonoma de Mexico (UNAM) \\ Mexico
}

\section{Introduction}

\subsection{Respiratory system structure and normal function}

The respiratory system is the gateway for 15,000 liters of air that enter through the nostrils, and after its appropriate conditioning, arrives to the delicate net structured by the lung parenchyma. At this site gas diffusion takes place, and oxygen diffuses through the Pneumocyte I cytoplasm to reach the erythrocyte's hemoglobin, passing by the endothelial cell.

To make this possible, a well-structured conducting system leads the air (trachea, bronchi, bronchioles, alveoli) from the nostrils to the alveoli. A specialized epithelium blankets the tubes, with some local modifications (Fortoul et al., 2010). This epithelium is constituted by a variety of cells with different functions (Figure 1).

In the submucose under the bronchi, mucous and serous glands are located, and liberate its secretion to the surface of the epithelium (Figure 2). These glands, as well as the goblet cells, produce mucus that in normal situations is Alcian blue/ PAS+ (Davis \& Dicker, 2008). The biochemistry of the mucus, produced by the goblet or the submucosal glands is important because they determinate their viscosity, $\mathrm{pH}$, and charge, as well as its stain affinity (Figure 3) (Rose \& Voynow, 2006).

With the help of intercellular junctions, this tubes system separates spaces between the epithelium, which is known as interstitial space and it houses connective tissue, fibroblast, lymphocytes, macrophages, and other cells that may migrate from the capillaries.

Along these tubes the air that enters through the nostrils becomes moistened, filtered and temperated, to arrive into the alveoli for gas diffusion. A change in the composition and function of the epithelial components will be associated with a variety of diseases which are associated to air pollutants exposure (Figure 4) (Mussali-Galante \& Fortoul, 2008).

\footnotetext{
" Rojas-Lemus, M. ${ }^{1}$, Rodriguez-Lara V. ${ }^{1}$, Cano-Gutierrez, G. ${ }^{1}$, Gonzalez-Villalva, A. ${ }^{1}$, Ustarroz-Cano, M. ${ }^{1}$, Garcia-Pelaez, I. ${ }^{1}$, Lopez-Valdez, N. ${ }^{1}$, Falcon-Rodriguez C.I. ${ }^{1}$, Silva-Martinez, J. ${ }^{1}$, Gonzalez-Rendon, E.S. ${ }^{1}$, Montaño, L.F. ${ }^{1}$, Cano-Gutierrez, B. ${ }^{1}$, Bizarro-Nevares P. ${ }^{1}$, Colin Barenque L. ${ }^{2}$ ${ }^{1}$ Departamento de Biologia Celular y Tisular, Facultad de Medicina, Universidad Nacional Autonoma de Mexico (UNAM), Mexico

${ }^{2}$ Departamento de Neurociencias, Iztacala, UNAM, Mexico
} 
Normal

Respiratory epithelium
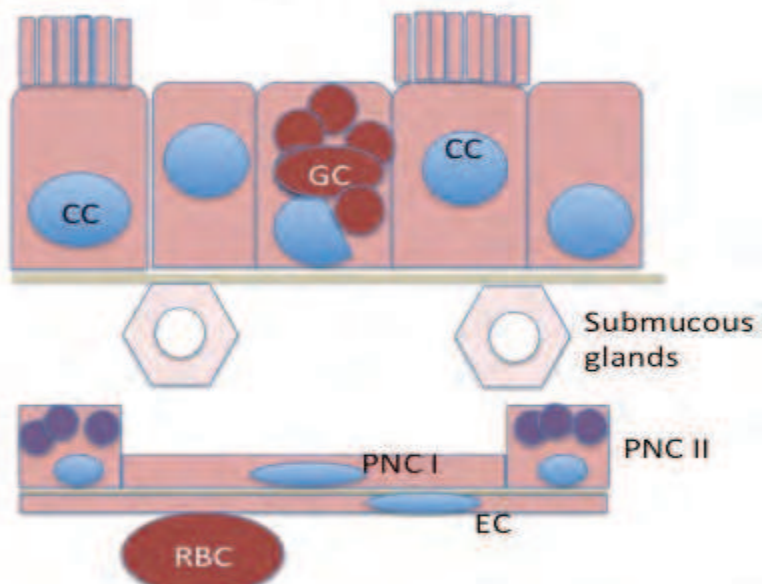

Normal

Alveolar epithelium

Fig. 1. Respiratory system epithelial cells. Ciliated Cell (CC), Goblet Cell (GC), Pneumocyte I (PNCI), Pneumocyte II (PNCII), Red Blood Cell (RBC), Endothelial Cell (EC).

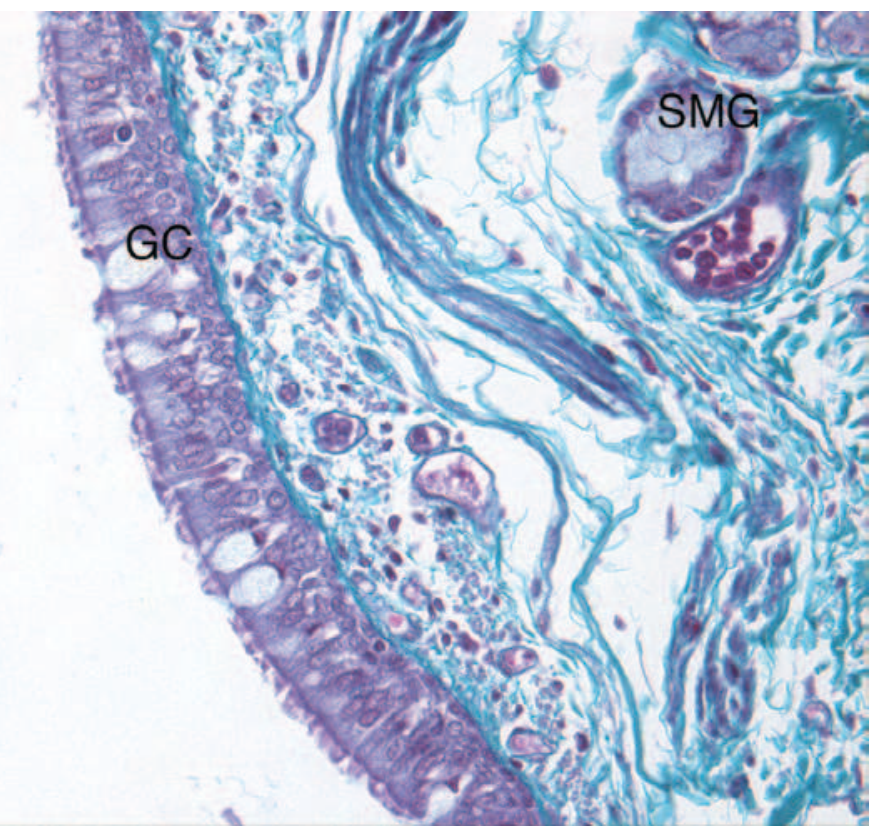

Fig. 2. Bronchial epithelium with Ciliated and Goblet Cells (GC). Submucose glands (SMC) with serous demilunes are also observed. 


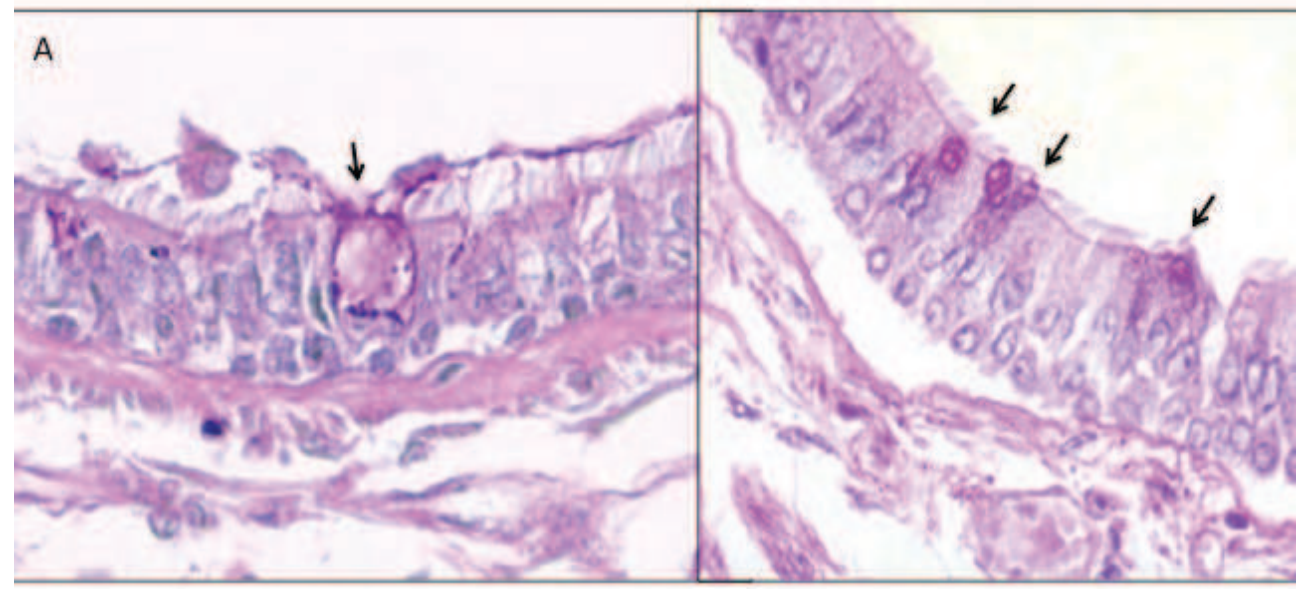

Fig. 3. Respiratory epithelium stained with PAS Schiff. (A) In normal situations, few PAS+ cells are observed (arrow). (B) In disease an increase in these cells is observed (arrows).

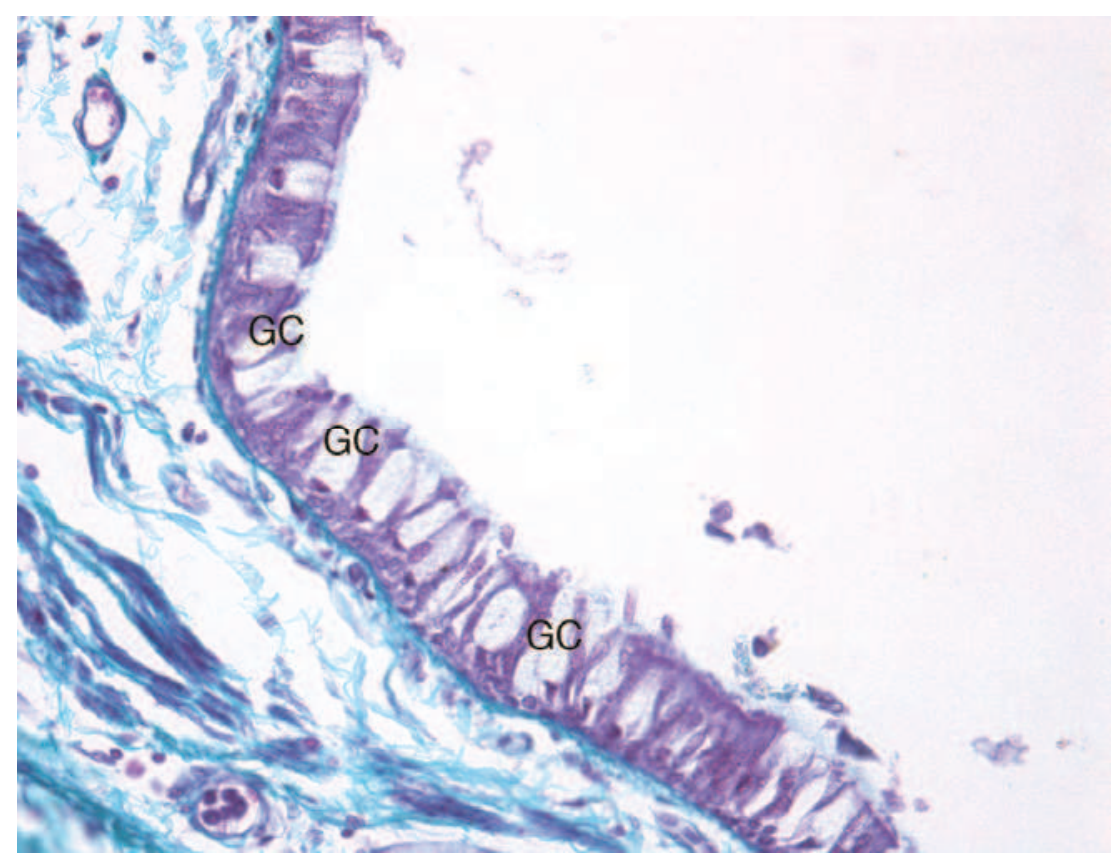

Fig. 4. The increase in the number of Goblet cells is a response of the respiratory epithelium to atmospheric aggressions. 


\subsection{Diseases associated with air pollutants (inflammation, fibrosis, COPD, asthma, cancer, immunologic modifications)}

Air pollutants, described latter in this chapter, induce different reactions and diseases. Inflammation as a consequence of the exposure to irritants such as Ozone, NOx, or particulate matter has been described (Yang \& Omaye, 2009). Also, fibrosis as a consequence of the exposure to gases is explored with more detail in a next section (Figure 5).

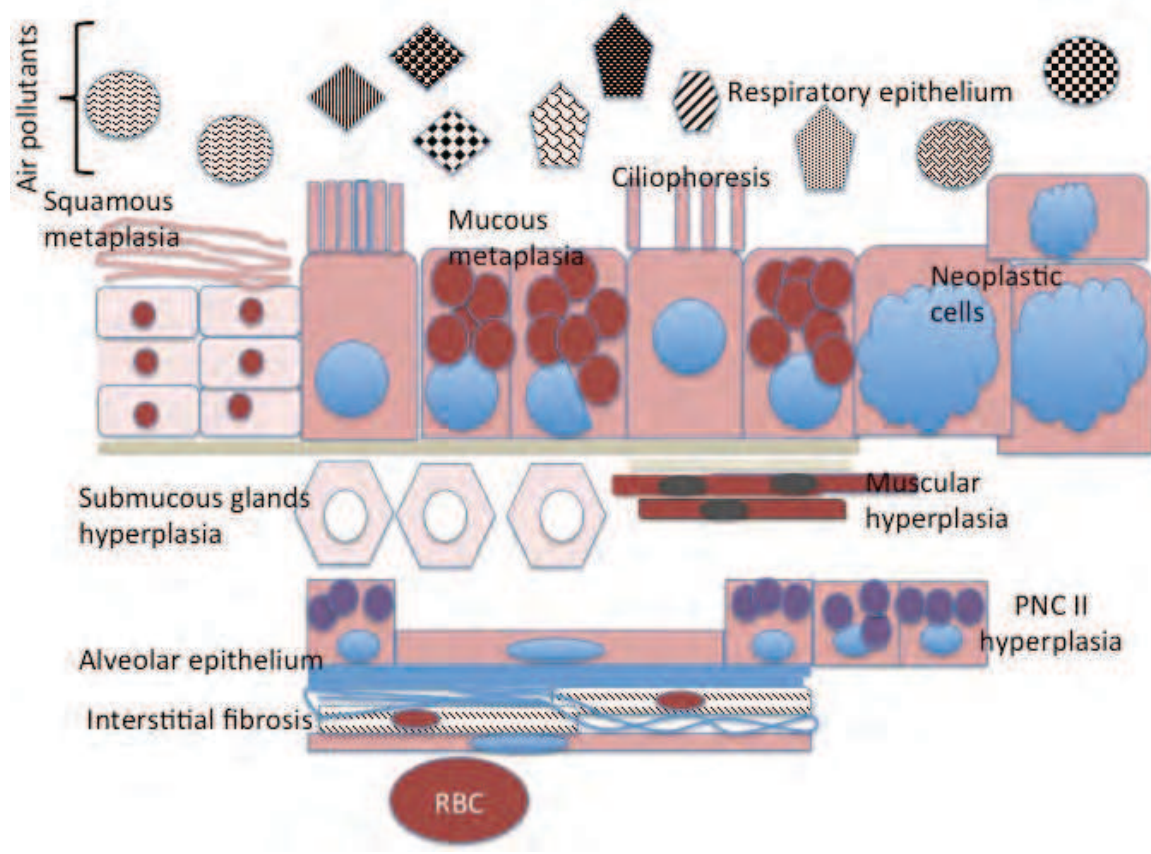

Fig. 5. Schematic representation of the changes that may be found in the respiratory epithelium, after its exposure to air pollutants.

Chronic Obstructive Pulmonary Diseases (COPD) included asthma, increases its frequency in cities with high atmospheric pollution (Olivieri \& Scoditti, 2005). The epithelium in these cases may increase the release of IL-6, TNF $\alpha, \mathrm{PGE}_{2}$, PDGF, TGF $\beta$, VEGF, and a variety of chemokines, and other mediators capable of inducing proliferation of fibroblasts and mucus production (Holgate, 2008).

In addition other components of air pollutants, such as metals, Volatile Organic Compounds (VOCs) are carcinogenic; other pathologies are associated with the exposure (Yang \& Omaye, 2009).

In the next sections the different responses of the lung to air pollutants will be explored.

\section{Air pollutants}

Air Pollutants are natural constituents of the air. Animals produce carbon dioxide as the end result of respiration, volcanic action produces sulfur oxides, and wind movement ensures 
the presence of suspended particulates. Pollutants are part of our everyday life, and it is difficult to remove them from the respirable air. However, man has caused a severe imbalance, in the natural mechanisms for atmosphere clearance, increasing the discharges of pollutants in the atmosphere, resulting in severe effects on human health (Atash, 2007).

\subsection{Classification of air pollutants}

Atmospheric pollutants have been classified according to their source; chemical composition, size and release form into indoor or outdoor environments (Bernstein et al., 2004):

A. Primary - secondary pollutants

1. Primary: pollutants emitted directly into the atmosphere

2. Secondary: pollutants that form in the air as a result of chemical reactions with other pollutants and gases.

B. Indoor - outdoor pollutants

1. Indoor pollutants

1.1 Sources: cooking and combustion, particle resuspension, building materials, air condition, consumer products, smoking, heating, biologic agents

1.2 Products: combustion products, $\mathrm{CO}, \mathrm{CO}_{2}$, Specific volatile organic compounds, microbial agents and organic dusts, radon, manmade vitreous fibers

2. Outdoor pollutants

2.1 Sources: industrial, commercial, mobile, urban, regional, agricultural, natural.

2.2 Products: $\mathrm{SO}_{2}$, ozone, $\mathrm{NO}_{x}, \mathrm{CO}, \mathrm{PM}$, Specific volatile organic compounds

C. Gaseous - particle pollutants

1. Gaseous: $\mathrm{SO}_{2}, \mathrm{NO}_{x}$, ozone, $\mathrm{CO}$, Specific volatile organic compounds

2. Particle: coarse $\mathrm{PM}\left(2.5-10 \mu \mathrm{m}\right.$; regulatory standard $\left.=\mathrm{PM}_{10}\right)$, fine $\mathrm{PM}(0.1-2.5 \mu \mathrm{m}$ regulatory standard $\left.=\mathrm{PM}_{2.5}\right)$; ultrafine $\mathrm{PM}(<0.1 \mu \mathrm{m}$; no regulated $)$.

\subsection{Gases}

Problems in air pollution were associated with high concentrations of sulfur dioxide $\left(\mathrm{SO}_{2}\right)$ in 20th Century. Through controlled exposure, human studies to $\mathrm{SO}_{2}(0.25 \mathrm{ppm})$ for only 5 minutes a rapid bronchoconstriction, in both healthy and asthmatic subjects was described. In patients exposed to inhalation of $\mathrm{SO}_{2}$ a relationship with TNF- $\alpha$ promoter polymorphism was identified, which is know to be associated also with asthma (Winterton et al., 2001; Bernstein et al., 2004).

Ozone is formed in the troposphere through a complex series of reactions involving the action of sunlight on nitrogen dioxide and hydrocarbons. The global concentration of $\mathrm{O}_{3}$ has increased due to an increase in nitric oxide emissions associated with the switch to fossil fuels during the industrial period. Nitric oxide is rapidly transformed into nitrogen dioxide by atmospheric oxidants such as ozone (Finlayson \& Pitts, 1997). Exposure to ozone causes a decreased in forced vital capacity and $\mathrm{FEV}_{1}$ associated with chest discomfort on inspiration and increased nonspecific airway hyper hyperresponsiveness (Bernstein et al., 2004).

$\mathrm{NO}_{2}$ is emitted directly into the atmosphere by combustion processes; however, the main source is the oxidation of $\mathrm{NO}$ by reactive species. Once $\mathrm{NO}$ is converted to $\mathrm{NO}_{2}$, a variety of reactions can generate nitrate radical $\left(\mathrm{NO}_{3}\right)$, dinitrogen pentoxide $\left(\mathrm{N}_{2} \mathrm{O}_{5}\right)$ (Finlayson \& Pitts, 1997). $\mathrm{NO}_{2}$ exposure $(2-6 \mathrm{ppm})$ induces an inflammatory response in the airways characterized by neutrophil influx and reduced lymphocyte subpopulations, also it might play a more prominent role as sensitizing agent to inhaled allergens (Strand et al., 1997). 
Carbon monoxide (CO) is produced by the incomplete combustion of carbon or carbon compounds. This gas can be bound to hemoglobin, forming carboxy hemoglobin and immobilizing hemoglobin function. Another compound of carbon, carbon dioxide is needed in plants' life cycle, in the reaction of photosynthesis. But its rise in the atmosphere in the presence of other gases such as methane and chlorofluorocarbons, is the cause of the greenhouse effect, (Raub et al., 2000).

\subsection{Suspended particles}

Particle air pollution is a mixture of solid, liquid or solid and liquid particles suspended in the air. The size of suspended particles varies, from a few nm to tens of $\mu \mathrm{m}$. The PM 10 (thoracic) are particles smaller than $10 \mu \mathrm{m}$ in diameter that can penetrate into lower respiratory tract; PM 2.5 (respirable) particles smaller than $2.5 \mu \mathrm{m}$ that can penetrate into gas-exchange region of the lung, and ultrafine particles smaller than $100 \mathrm{~nm}$ which have a limited contribution to particle mass, but which in terms of numbers are more abundant than the other sizes, and offer a very large surface area, with increased degrees of lung penetration.

Major natural sources of particles include organic material terrestrial dust caused by winds, sea spray, biogenic emissions, volcanic eruptions and wild fires; the contamination through anthropogenic or technogenic is produced by combustion, industrial waste, nuclear energy, anthropogenic fire, and burning of household waste (Finlayson-Pitts \& Pits, 2000). Metal particles (mercury, cadmium, nickel and lead) are part of PM2.5.

\section{Lung development modifications by air pollutants}

The respiratory system begins its development at the 4th week of pregnancy, in the fetal larynx as a respiratory primordium. This structure is covered by endoderm that will differentiate into the respiratory epithelium, and the respiratory glands.

Other structures will be developed from the splanchnic mesoderm that surrounds the endoderm.

The regulation of the respiratory system morphogenesis is coordinated by different structures, in different time periods. It has been reported the expression of molecules such as Fibroblast Growth Factor (FGF), sonic hedgehog, Bone Morphogenic Protein (BPM), retinoic acid and Wnt signaling pathways, as well as various transcription factors as part of this regulatory network (Cardoso \& Lü, 2006).

At the end of the 7-week, the lungs are already developed, but its maturation is extended during the pre and postnatal periods. $80 \%$ of the alveolar tissue ends its development until the end of adolescence. This large maturation time exposes the lung to suffer damage and modify its development; this also increases the risk for developing pulmonary diseases early in adulthood such as restriction or a decrease in lung function (Wang \& Pinkerton, 2008; Rojas-Martinez, et al., 2007).

Prenatal exposure to Environmental Tobacco Smoke (ETS) has been associated with an increased risk of asthma, and during the postnatal period, the exposure increases asthma exacerbations, as well as the risk for respiratory infections (Wang \& Pinkerton, 2008). Studies in mice indicate that prenatal exposure to ETS increases allergic responses in postnatal period (Penn et al., 2007; Gern, 2010).

The exposure to outdoor pollutants such as Particulate Matter (PM), carbon monoxide (CO), sulphur $\left(\mathrm{SO}_{2}\right)$, nitrogen (NOx), and ozone, decreases lung function during childhood 
(Mortimer et al., 2008). Also $\mathrm{O}_{3}$ exposures increase hyper-reactivity along with an increase in TNF-a, IL-1b, KC, IL-6, and MCP-1 with non-visible structural lung modifications (Auten et al., 2009).

\section{Xenobiotic metabolism}

\subsection{Lung metabolic active cells}

The lung is one of the main sites for xenobiotics metabolism and in some cases, biotransformation (Castell et al., 2005). Biotransformation is the process by which cells modify xenobiotics, with the ultimate goal of facilitating the elimination of lipophilic substances. These reactions are classified in three phases. Phase I: Enzymes encoded by cytochrome P450 (hemoproteins actively involved in the biotransformation of xenobiotics). Phase II: Reactions tend to render more water-soluble products and less active metabolites, and finally, Phase III: Elimination (Choudhary et al., 2005).

More than 40 different types of cells have been described in the lung (Pavek \& Dvorak, 2008), and some are metabolically active. Immunohistochemical analysis has evidenced the presence of cytochrome P450 (Cytochrome Proteins) (CYP) in lung cells such as: macrophages (Pavek \& Dvorak, 2008), endothelium, alveolar cells types I and II, ciliated cells (Castell et al., 2005) and Non-Ciliated Bronchiolar Cell or Clara cell. Clara cells are the leading cells for xenobiotic metabolism in the lung because its profuse cytochrome P450 mono oxygenase activity (Katavolos et al., 2009).

\subsection{CYPs and lung metabolism (CYPs and cell metabolism)}

CYP families and subfamilies are responsible of the oxidative metabolism of the majority of xenobiotics such as: drugs, environmental pollutants and carcinogens. The main families are: CYP1, CYP2 and CYP3 and comprise about half of the total CYPs. The subfamilies are classifieds according to the degree of nucleonic and amino acid sequence homology (Castell et al., 2005). All CYPs are localized in the cell's smooth endoplasmic reticulum. CYP 450 enzymes act as mono oxygenases, and use one atom of molecular oxygen to oxidase xenobiotics, requiring the aid of NADPH-cytochrome $\mathrm{P} 450$ reductase, to provide the electrons required for the reduction of the second oxygen atom to $\mathrm{H}_{2} \mathrm{O}_{2}$ (Ioannides, 2008). The lung contains a variety of subfamilies such as: CYP1A1, CYP1B1, CYP2A6, CYP2B6, CYP2E1, CYP3A5 (Castell et al., 2005), CYP2B1, CYP3A1 (Pons et al., 2000), CYP2F1, CYP2F2 (Carlson, 2008) and CYP2S1 (Deb \& Bandiera, 2010).

\subsection{Air pollution modification of CYPs}

Air pollution increases or decreases the CYPs amount in the lung. Exposure to environmental factors such as: dioxins as 2,3,7,8-Tetrachlorodibenzo-p-dioxin (TCDD), polycyclic aromatic hydrocarbons $(\mathrm{PAH})$ as benzo [a] pyrene $(\mathrm{BaP})$ and tobacco smoke (Chang et al., 2006), enhances CYP1A1 activity and has been reported to be a prognostic factor for lung cancer development. (Ioannides, 2008). CYP1B1 and CYP2S1 also increase its activity after the exposure to PAH and BaP (Deb \& Bandiera, 2010), also CYP1A1 and CYP1B1 are localized in the Clara cell (Chang et al., 2006). PAH and BaP also bind to arylhidrocarbonyl receptor (AhR) that translocates to the nucleus and acts as a transcription factor that binds to a specific DNA recognition sequence, termed the xenobiotic responsive element (XRE) (Anwar-Mohamed et al., 2009) and all CYPs can generate ROS during NADPH-dependent CYP catalysis (Ioannides, 2008) (Figure 6). 


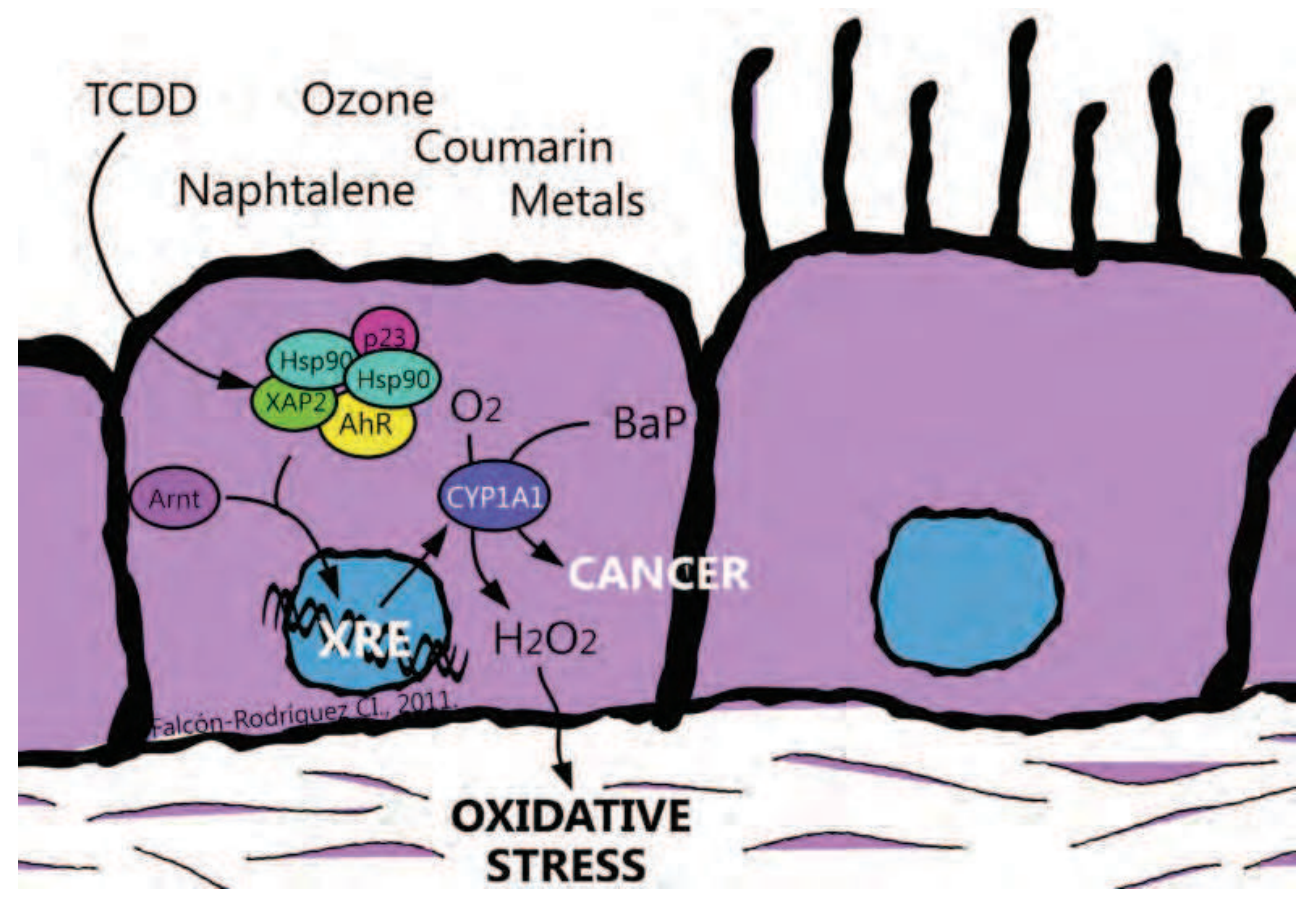

Fig. 6. Molecular mechanism of CYP1A1 activation by AhR signal transduction pathway in Clara cell (Bronchiolar epithelium. A ligand enters to the cell (TCDD) and binds to the cytosolic complex of AhR, chaperones hsp90, co-chaperone p23. Ligand-AhR complex translocates into the nucleus. AhR-ARNT heterodimer then binds to xenobiotic response element (XRE).

Other hydrocarbons as toluene, occurs naturally in crude oil and in the tolu tree. It is also produced in gasoline process, fuels from crude oil, making coke from coal and it is used in paints and paint thinners. Toluene exposure enhances CYP2B1 activity in rat lung (Pons et al., 2000). Naphthalene, derived from petroleum, coal, and tobacco smoke (Morris \& Buckpitt, 2009), increases CYP2F2 activity. In mouse lung CYP2F2 the metabolism rate was $107 \mathrm{nmol} / \mathrm{min} / \mathrm{nmol} \mathrm{P} 450$, whereas for human lung CYP2F1 was $0.045 \mathrm{nmol} / \mathrm{min} / \mathrm{nmol}$ P450 (Carlson, 2008). Other products such as coumarin, a natural product used widely as a fragrance ingredient, and also been used clinically at high dosages in humans for the treatment of high-protein lymphedemas, and as an antineoplastic agent in the treatment of renal cell carcinoma and malignant melanoma. The Coumarin-Epoxidation increases the expression of CYP2F2, and shows a specific metabolism in mouse Clara cell (Born et al., 2002). Furthermore, Clara cell does not contain CYP2E1, but, when rats are exposed to ozone, the CYP2E1 is induced in the bronchiolar epithelium (Ioannides, 2008). In general Particulate Matter induces gene expression of CYP1A1 and CYP2E1 (Abbas et al., 2009). Finally, metals are components of Total Suspended Particles (PST). Scarce information is available on the metal effects on lung CYPs, although, demonstrated recently that $\mathrm{V}^{5+}$ was able to decrease the TCDD-mediated induction of CYP1A1 mRNA, protein and catalytic activity (Anwar-Mohamed et al., 2009). 


\section{Air pollutant effects on respiratory system}

There are changes associated with atmospheric pollutants that are evidenced with different patterns and diseases. Changes in the local lymphoid tissue, carcinogenic and genotoxic changes, fibrosis, COPD, are some of the outcomes observed after air pollution. Inflammation is core event in all the changes observed after the contact of the epithelial cells with the air pollutants, so it will be the first described in this section.

\subsection{Inflammation and air pollution}

The first suggestion of the consequences of air pollution date back to the serious events that occurred in Belgium in 1948 in the so called "killer fog" incident, and in the so called "London fog" that happened in the first week of December 1952 and provoked 4000 more deaths than those expected. After those episodes air pollution control policies were introduced since it became clear that air pollution was associated with an increase in morbidity and mortality in individuals with cardiovascular disease or with chronic obstructive pulmonary disease (Mills et al., 2009). The root of this increased mortality lay in the lung chronic inflammation that affects the pulmonary vascular endothelium, the thrombotic potential and the fibrinolitic balance in exposed individuals. These processes favor atherosclerotic plaque rupture, thrombosis and translocation of particulate matter to the blood, through the pulmonary capillaries; the latter affects directly the body vascular endothelium leading to the loss of endothelium integrity thus initiating a pulmonary and a systemic inflammatory reaction (Mills et al., 2006). A fraction of the translocated particulate matters accumulates in the liver, the spleen, the thymus and others (Nemmar et al., 2002).

Ambient particulate matter $(\mathrm{PM})$ is a mixture of inhalable particles that are considered as serious contaminants. These particles come from the combustion of biomass fuels used for cooking and heating homes, emissions from internal combustion motors and industrial machinery, and forest fires (Torres-Duque et al., 2008). This matter has been grouped in coarse $(2.5-10 \mu \mathrm{m})$ and fine $(2.5 \mu \mathrm{m}$ or less) depending on their diameter.. Both types induce serious health consequences in exposed individuals. Both types of particles penetrate into the lung, however the coarse particles are more dangerous because of their mass (Hetland et al., 2005). Obviously there are many inherent conditions in the exposed individual that increase the risk to develop cardiovascular or pulmonary disease: alfa- 1 antitrypsin deficiency, family history of chronic obstructive pulmonary disease or atherosclerosis, personal history of frequent upper respiratory tract infections, hypersensitivity to inhaled irritants, tobacco, asthma, and being female (Ekici et al., 2005). Also, we must consider the enhanced air pollution in overcrowded cities with serious traffic problems. These cities usually have a higher concentration of PMs in the air. An increase of $7 \mu \mathrm{g} / \mathrm{m} 3$ in the PM2.5-10 concentration is associated with a $5 \%$ decrease in FEV1 and an odds ratio of 1.33 for chronic obstructive pulmonary disease in women compared with men (Schikowski et al., 2005).

Both types of particles recruit and activate neutrophils, but PM2.5-10 induces a higher proinflammatory activity (Wegesser \& Last, 2009). There are important differences in the relative concentration and type of components (metals, organic compounds, ultrafine particles adhered to larger particles) (Donaldson et al., 2005) between coarse and fine particles that depend on the season and geographic site where the sample is collected (Seagrave et al., 2006).

Other constituents of ambient particulate matter are biological materials, especially bglucans, fungi spores and endotoxins that derive from gram-negative bacteria (Schwarze et 
al., 2006). It has been shown that PM constituent responsible for the pro-inflammatory activity induced by PM2.5-10 are endotoxins and particularly a soluble fraction known as lipopolysaccharides (LPS) (Schins et al., 2004). The concentration of endotoxin in PM depends on the site and season, as we have already mentioned, but environmental humidity is associated with endotoxin concentration in particulate matter (Spaan et al., 2008). One example of the impact of biological components in PM is the heat shock protein HSP60 derived from Chlamydia pneumoniae, detected in PM2.5-10 that promotes lung inflammation and pulmonary dendritic cells activation through the innate immune response receptor TLR4 and the MyD88 pathway. The inflammation induced by HSP is secondary to an increase in the number of immune-related cells in the broncho alveolar lavage (BAL), enhanced recruitment of neutrophils, increased synthesis of IL-6 and over-expression of CD80 and CD86 in BAL dendritic cells (Bulut et al, 2009). HSP60 also activate pulmonary macrophages and endothelial cells through TLR4 in a MyD88-dependent pathway (Bulut, 2002). Interestingly, and independently from its endotoxin content, PM2.5 per se activate macrophages through TLR-2 y TLR-4 (Shoenfelt et al., 2009). Similarly, the respiratory epithelium, the first point of contact for inhaled foreign organism, also express TLR4 and secrete, upon activation, pro-inflammatory cytokines and chemokines that recruit neutrophils and T lymphocytes to the infection site (Parker \& Prince, 2011).

Pulmonary inflammation induced by exposition to or inhalation of PM is closely related to particle processing by alveolar macrophages. Once these macrophages become activated a cascade of pro-inflammatory cytokines is initiated leading to endothelial damage. A recent study shows that in the presence of PM2.5-10 the amount of alveolar macrophages is duplicated and the amount of activated macrophages triplicates leading to persistent lung and systemic inflammation that were both associated with vascular endothelial dysfunction (Tamagawa et al., 2008). The increase in IL-6 serum concentration in PM2.5-10 exposed individuals was important during the first two weeks of exposure and was directly related to the amount of activated macrophages; afterwards, the concentration of IL- 6 was similar in exposed individuals and controls. Alveolar macrophages activated with PMs secrete TNF-a, granulocyte-monocyte colony stimulating factor, and IL-1b (van Eeden et al., 2001). It is highly probable that these cytokines act not only locally but systemically thus generating a more organized inflammatory response that include the bone marrow. The acute exposure to PMs induces a rapid bone marrow response liberating leukocytes and platelets into the systemic circulation. As far as inflammatory cytokines in the pulmonary inflammation process, it has been shown that IL-6 inhibits directly the expression of eNOS thus diminishing nitric oxide production by the endothelium (Saura et al., 2006). Chemokine secretion is also altered in individuals exposed to particulate matter. Interleukin 8 , a chemokine responsible for the recruitment and activation of pulmonary neutrophils in inflammation sites, binds to PMs (Seagrave, 2008). Activated neutrophils and macrophages secrete IL-8 and IL-1b.The excessive recruitment of neutrophils is clearly detected in BAL samples of individuals exposed to particulate matter.

A recent study analyzed the effect of daily changes in particulate matter air pollution upon the inflammatory cells response. The results showed that as the concentration of PM2.5-10 increases in the air the serum concentration of fibrinogen and the expression of E-selectin in exposed individuals increases whereas the concentration of prothrombin and von Willebrand antigen diminishes. The serum concentration of $C$ reactive protein, coagulation factor VII, amyloid A and the soluble ICAM-1 fraction was not modified (Hildebrandt et al., 2009). Fibrinogen is an acute phase protein and a coagulation factor synthetized by the liver 
in response to elevated IL-6 serum concentration (Gabay \& Kushner, 1999). E-selectin reflects the activation of the vascular endothelium and it is well known that the increased expression of this adhesion molecule is associated with the serum concentration of inflammatory cytokines such as TNF-a, IFN-y and IL-6 (Rice \& Bevilacqua, 1989) as well as the recruitment of leukocytes and T lymphocytes in the inflammation zone. The presence of neutrophils in an IL-6 enriched environment enhances the expression of E-selectin in endothelial cells but also its apoptotic death thus perpetuating the inflammatory damage (Barnes et al., 2011). It has also been shown that prolonged exposure to PM2.5 is associated with an important plasmatic increase in endothelin-1 concentration and in an increased pulmonary artery pressure (Calderon-Garcidueñas et al., 2007). The contribution of all these processes in the lung keeps the inflammatory process alive.

Heat inactivation of PM2.5-10 diminishes the expression of CD14, CD11b/CR3 y HLA-DR and the phagocytic activity of alveolar macrophages (Alexis et al., 2006) but its influence in neutrophil recruitment into the airways is still controversial. Exposures to viruses, increase the serum concentration of INF-g, previous to the inhalation of particulate matter induce a stronger pulmonary inflammation response that include oxidative damage to the lung. The result of these changes is a loss in the antibacterial function of neutrophils and alveolar macrophages and consequently, an increase in the local content of bacterial endotoxins (Sigaud et al., 2007) that perpetuates the pulmonary inflammation. Sigaud and coworkers (2007) also demonstrated that macrophages exposed to PMs have an enhanced expression of multiple inflammation-related genes: MCP-5, IL-9, IL-17B, IL-1b, MIP-1b, MIP-3b, IL-8R, C10, CCR-1, CCR-2 and MDC.

In summary, exposure to particulate matter induces excessive production of proinflammatory cytokines and chemokines by alveolar macrophages and lung dendritic cells, both of which are activated through TLR2 and TLR4 and the MyD88 signaling pathway. The excessive amount of these inflammatory molecules directly affect the pulmonary and systemic vascular endothelium by diminishing its capacity to regulate properly its vascular tone and permeability, triggering abnormal coagulation and fibrinolysis mechanisms, and increasing the adhesion of inflammatory cells to the vascular endothelium.

\subsection{Bronchial associated lymphoid tissue (BALT) modifications}

Bronchus-associated lymphoid tissue (BALT) is a constitutive mucosal lymphoid tissue adjacent to major airways. BALT is composed by B cells surrounded by a parafollicular region of T cells, dendritic (DCs) and macrophages. As the result of air pollution BALT can acquire antigens, allergens or contaminants from the airways, then complex interactions occur increasing its efficiency. For example, BALT can initiate local immune responses and the amount of BALT increases (Randall, 2010).

The presence of BALT in adult mammals depends on species, antigen stimulation and age. BALT is found in normal lungs of most healthy adult rabbits, rats, guinea pigs and old adult mice. In contrast, the presence and frequency of BALT in normal lungs of healthy adult humans is controversial (Kawamata et al., 2009).

In humans BALT is neither found at birth nor in healthy adults but transiently arises during childhood and adolescence. In both humans and mice, air pollution can induce BALT, data derives from splenectomized lymphotoxin $\alpha$-deficient mice, which lack all secondary lymphoid organs but do develop BALT. This suggests that BALT can serve as induction sites for adaptive immune responses to contaminants. However, mechanisms that control the development and maintenance of BALT are largely unknown (Halle et al., 2009). 


\subsection{Carcinogenic and mutagenic effects}

Lung cancer is the leading cause of cancer death worldwide. Smoking is the major risk factor for lung cancer. Although some subjects who have never smoked get lung cancer, smoking causes 9 out of 10 cases of this pathology. So there are other factors that promote the carcinogenic process. It has been reported that air pollution exposure may cause lung cancer. In a six US cities study, Dockery and coworkers (1993) found that the greatest effects were for lung cancer and cardiopulmonary disease, between the least and most polluted cities. Pope et al. (1995) found increased long-term effects on cardiopulmonary mortality and lung cancer in a 17-year follow-up (Naess et al., 2007). Also, Cao and coworkers (2011) analysis provides the first prospective evidence in China that air pollution (e.g., SO2) may contribute to the increased risk for lung cancer mortality. In Europe, the proportion of lung cancers attributable to urban air pollution is estimated to be $11 \%$ (Molina et al., 2008). Likewise, it have been reported that the type of lung cancer is related to air pollution, for example, in a Spain study, individuals living near industries displayed an excess risk of lung cancer $(\mathrm{OR}=1.49 ; 95 \% \mathrm{CI}=0.93-2.39)$, which attained statistical significance for small cell carcinomas $(\mathrm{OR}=2.23 ; 95 \% \mathrm{CI}=1.01-4.92)$, residents in urban areas showed a statistically significant increased risk for adenocarcinoma (OR=1.92; 95\% CI=1.09-3.38). In Aviles a health area, no differences in risk was found (López-Cima et al., 2011).

Urban air, particularly in densely populated urban environments, contains inorganic particulates (arsenic, asbestos, chromium, cadmium, lead and nickel), radionuclides $(210 \mathrm{~Pb}$, $212 \mathrm{~Pb}$ and $222 \mathrm{Rn}$ ), gaseous and particulate organic species (benzene, benzo[ $\alpha]$ pyrene, 1,3butadiene and benzene-soluble organics), oxidants such as ozone and sulfur and nitrogen oxides in particle form. These substances are present as components of complex mixtures proceeding basically from industries emissions, combustion of fossil fuels for power generation or transportation, and all are related with carcinogenesis process (Naess et al., 2007).

Particulate matter (PM), especially fine particles of less than $2.5 \mu \mathrm{m}$ in diameter (PM2.5) is related with lung cancer (Perez-Padilla et al., 20010). Pope and coworkers (2002) reported that each $10-\mu \mathrm{g} / \mathrm{m} 3$ elevation in long-term average PM2.5 ambient concentrations was associated with approximately a $8 \%$ increased risk of lung cancer mortality, although the magnitude of the effect somewhat depended on the time frame of pollution monitoring. Particulate matter contains a lot of compounds that are considered human carcinogens like heavy metals such as cadmium, cobalt, chromium and nickel. Several epidemiological studies have clearly demonstrated that exposure to metals has toxic and carcinogenic affects in animals and humans; some of them have been demonstrated to be lung carcinogenesis promoters (Salnikow \& Zhitkovich, 2008). Human cadmium exposure is associated with lung cancer. Also in animal models, cadmium induces lung carcinomas after inhalation (Beyersmann \& Hartwig, 2008). At the cellular level, this metal affects cell proliferation, differentiation, apoptosis, and other cellular activities and may cause numerous molecular lesions that would be relevant to carcinogenesis (Mates et al., 2010). Inorganic cobalt compounds, both soluble and particulate forms, caused lung tumors in animal experiments (Beyersmann \& Hartwig, 2008). The IARC recently classified the mixture cobalt/tungsten carbide (Co/WC) as carcinogenic to humans (Mates et al., 2010).

Chromium is other carcinogenic metal. Epidemiological studies have consistently shown that the lower respiratory tract is the target organ of $\mathrm{Cr}(\mathrm{VI})$ compound exposure, and 
occupational exposure to these compounds is strongly associated with a higher incidence of lung cancer. Chromium exists in the environment in two major valence states, $\mathrm{Cr}(\mathrm{VI})$ and chromium (III) [Cr(III)], and $\mathrm{Cr}(\mathrm{VI})$ is actively transported into cells by the anionic transport system. The reduction of $\mathrm{Cr}(\mathrm{VI})$ to $\mathrm{Cr}(\mathrm{III})$ can lead to the formation of DNA-chromium adducts, DNA-DNA and DNA-protein cross-links, DNA-Cr(III)-amino acid ternary complexes and radical-mediated DNA strand breaks. In addition, it has been reported that lung cancer from workers exposed to $\mathrm{Cr}(\mathrm{VI})$ has a high percentage of $\mathrm{G}$ to $\mathrm{T}$ transversion mutations in the non-transcribed strand of the p53 gene (Feng et al., 2003). Chromium compounds also are capable to induce oxidative stress and the deregulation of cell proliferation (Beyersmann \& Hartwig, 2008). On the other hand, several epidemiological studies demonstrated a strong correlation between nickel exposure and risk of lung and nasal cancer, especially in the case of workers at nickel refineries. Evidence from experimental animals has demonstrated the carcinogenicity of metallic nickel, which is also classified as possibly carcinogenic to humans (Group 2B). Nickel carcinogenesis involves epigenetic alterations, disruption of cellular iron homeostasis (by interfering with irondependent enzymes), generation of ROS, and activation of the hypoxia-signalling pathway (Salnikow \& Zhitkovich, 2008).

Sulfur oxide pollution (as measured by sulfate particles and/or sulfur dioxide) is significantly associated lung cancer mortality. Elevated mortality risks have been associated primarily with measures of fine particulate and sulfur oxide pollution (Naess et al., 2007; Pope et al., 2002). Inhalation exposure to air pollutants, e.g., SO2, has been associated with the DNA damage of multiple organs including the lung, providing a possible biological pathway through which air pollution may affect lung cancer incidence (Cao et al., 2011).

Exposure to nitrogen oxide (NOx and NO2) also is related to lung cancer (Naess et al., 2007; Raaschou-Nielson et al. 2010). Studies have been shown that women had particularly large effects for lung cancer in the young age group, somewhat less so for the old exposed to nitrogen oxide (Naess et al., 2007). Moreover NOx exposure has significant correlations with adenocarcinoma (AC) type cancer incidence rates for both genders (Chen et al., 2009), although women seem to be more susceptible (Liaw et al., 2010). NOx may potentially trigger mutagenic and carcinogenic activity and play significant roles in the metabolism and behavior of AC type lung cancer (Fujimoto et al., 1998). It appears that the higher the NOx concentration, the higher the $\mathrm{AC}$ incidence rate. Recent studies on the role of $\mathrm{NO}$ in tumor progression suggest that $\mathrm{NO}$ is an important bioregulatory and signaling molecule and may play a role in the process of carcinogenesis (Tamir \& Tannenbaum, 1996). NO is an endothelial growth factor that specifically mediates tumor vascularization (Jenkins et al., 1995) and tumor blood flow (Tozer et al., 1997). Exposure of cells to high NO concentrations cause DNA damage and apoptosis. Moreover, recent results have shown that NO stimulates p53 accumulation (Forrester et al., 1996). In summary, according to previous literature, NO and its derivatives can cause DNA damages (Wink et al., 1993) and play important roles in human lung AC (Fujimoto et al.,1998) (Liaw et al., 2010).

Airborne polycyclic aromatic hydrocarbons (PAHs) are emitted when organic matter is burned. It has long been known that several PAHs can produce cancers in experimental animals, and epidemiologic studies of exposed workers, especially in coke ovens and aluminum smelters, have shown clear excesses of lung cancer (Bostrom et al., 2002; Ben et al., 2004). PAHs have been suggested as being responsible for the initiation and development of lung cancer. PAHs and their metabolites are involved in mechanisms of 
carcinogenesis; produce early chromosomal changes, transformation of cells in culture, cytotoxicity and mutagenicity. The benzo(a)pyrene (BAP) for example, directly damages p53. In smoking-related lung cancer, $40 \%$ of the p53 gene mutations are $G$ to $T$ transversions, and $90 \%$ of this type of mutation can be attributed to the non-transcribed (coding) strand. $\mathrm{G}$ to $\mathrm{T}$ transversion has been regarded as a hallmark of PAH-induced mutations in smoking-related lung cancer. Activated metabolites of PAHs in cigarette smoke, including benzo[a]pyrene diol epoxide (BPDE), preferentially form DNA adducts at methylated $\mathrm{CpG}$ sites along the p53 gene corresponding to the afore mentioned major mutational hotspots in smoking-related lung cancer (Feng et al., 2003).

On the other hand, radon gas is a naturally occurring radioactive gas that can seep out of the soil into buildings, also emanates from uranium-bearing soil and porous rock. Radon is the second biggest cause of lung cancer after smoking. The cancer risk from radon increases the risk from smoking. Radon induces damage to a checkpoint tumor suppressor gene such as Tp53 (which codes for p53) since alpha particle radiation is a key mechanism for radonrelated lung cancer (Harley et al., 2008; Bissett \& McLaughlin 2010). Some studies suggest a relationship between the AGGARG-ATGMET transversion in codon 249 of P53 from people exposed to high radon concentrations (Ruano-Ravina et al., 2009). The damage done to epithelial cells of the lung occurs when radiation interacts either directly with DNA in the cell nucleus or indirectly through the affect of free radicals (UNSCEAR, 2000). Recently, in vitro studies of cells exposed to alpha-particle radiation gave evidence that more cells showed damage than those that were traversed by alpha-particles (Sawant et al., 2001; Alavanja 2002). Radon produces oxidative stress, although some similarities in the increased frequency of p53 mutations at a later stage in this process, DNA damage in the form of sister-chromatid exchange and mutations, have been observed for both smokers and those exposed to radon gas (Alavanja 2002). Other studies provided evidence of a GSTM1 and radon interaction in the increasing risk for lung cancer. Glutathione-S-transferase M1 (GSTM1) conjugates known carcinogens such as epoxides of polycyclic aromatic hydrocarbons (Risch \& Plass, 2008). Other studies show that radon exposure in miners induces gene mutations and chromosomal aberrations. Numerous in vitro cytogenetic studies demonstrated that radon induces different types of genetic and cytogenetic damage that is likely to play a role in radon lung carcinogenesis (Al-Zoughool \& Krewski, 2009).

\subsection{Genotoxic effects}

Generation of DNA damage is considered an important initial event in carcinogenesis. Multiples assays exist for the detection of different genotoxic effects of compounds in experimental systems, or for exposure investigation for genotoxic agents in environmental or occupational settings (Moller 2005). Cells with DNA damage are more susceptible to develop mutations after exposure to xenobiotics (Olive et al. 2001). For this reason, genotoxic evaluation of environmental pollutants is necessary in the respiratory system, because it is the first contact for inhaled xenobiotics.

Studies on environmental pollution (and their components), genotoxicity and respiratory tract, have been carried out in vivo and in vitro. Table 1 summarizes the results obtained in the last years.

A number of studies have considered DNA damage as an endpoint for the effects of air pollutants (Vineis \& Husgafvel- Pursiainen 2005). In this report, we evidence the results 
obtained by genotoxic profiles, indicating that air pollutants cause alterations in the genetic material of the tested cells (strand breaks [illustrate in Figure 7], oxidative damage, adducts and micronucleus). DNA damage could provoke mutations in any cell from the respiratory tract and, may facilitate the development of neoplastic events.

\begin{tabular}{|c|c|c|c|c|c|}
\hline & Exposure & System/Tissue & End Point & Results & Reference \\
\hline \multicolumn{6}{|l|}{ In vivo } \\
\hline & $\begin{array}{r}\mathrm{DEP} \\
\text { Inhalation }\end{array}$ & $\begin{array}{r}\text { Big Blue rats } \\
\text { Male } \\
\text { Lungs }\end{array}$ & $\begin{array}{r}\text { Mutant frequency } \\
\text { Mutation spectra } \\
\text { DNA adducts } \\
\text { 8-OHdG levels }\end{array}$ & $\begin{array}{l}+ \\
+ \\
+ \\
+\end{array}$ & $\begin{array}{r}\text { Sato et al., } \\
2000\end{array}$ \\
\hline & $\begin{array}{r}\mathrm{DEP} \\
\text { Inhalation }\end{array}$ & \begin{tabular}{|r|} 
Mice \\
Female \\
Lungs \\
Bronchioalveola \\
r lavage cells \\
\end{tabular} & $\begin{array}{r}\text { 8-OHdG levels } \\
\text { DNA strand breaks } \\
\text { (comet assay) }\end{array}$ & $\begin{array}{l}+ \\
+\end{array}$ & $\begin{array}{r}\text { Risom et al., } \\
2003\end{array}$ \\
\hline & $\begin{array}{r}\mathrm{DEP} \\
\text { Inhalation }\end{array}$ & Mice & $\begin{array}{r}\text { DNA adducts } \\
\text { DNA strand breaks } \\
\text { (comet assay) } \\
\text { DNA oxidative damage } \\
\text { Mutation frequency } \\
\end{array}$ & $\begin{array}{l}+ \\
+ \\
+ \\
-\end{array}$ & $\begin{array}{r}\text { Dybdahl et } \\
\text { al., } 2004\end{array}$ \\
\hline & $\begin{array}{r}\text { Environmental } \\
\text { Pollution }\end{array}$ & $\begin{array}{r}\text { Human } \\
\text { Females/males } \\
\text { Nasal epithelial } \\
\text { cells }\end{array}$ & $\begin{array}{r}\text { DNA strand breaks } \\
\text { (comet assay) }\end{array}$ & + & $\begin{array}{r}\text { Fortoul et } \\
\text { al., } 2010\end{array}$ \\
\hline \multirow[t]{5}{*}{ In vitro } & $\mathrm{DEP}$ & A549 cells & $\begin{array}{r}\text { DNA strand breaks } \\
\text { (comet assay) }\end{array}$ & + & $\begin{array}{r}\text { Dybdahl et } \\
\text { al., } 2004 \\
\end{array}$ \\
\hline & $\begin{array}{r}\text { Particulate } \\
\text { Matter (PM2.5 } \\
\text { and PM 10) } \\
\end{array}$ & A549 cells & $\begin{array}{r}\text { DNA strand breaks } \\
\text { (comet assay) }\end{array}$ & + & $\begin{array}{r}\text { Gutierrez- } \\
\text { Castillo et } \\
\text { al., } 2006 \\
\end{array}$ \\
\hline & $\begin{array}{r}\text { Particulate } \\
\text { Matter (PM10) }\end{array}$ & A549 cells & Micronucleus & + & $\begin{array}{r}\text { Roubicek et } \\
\text { al., } 2007\end{array}$ \\
\hline & Fine Particles & A549 cells & $\begin{array}{r}\text { DNA strand breaks } \\
\text { (comet assay) }\end{array}$ & + & $\begin{array}{r}\text { Sharma et } \\
\text { al., } 2007 \\
\end{array}$ \\
\hline & $\begin{array}{r}\text { Nitrogen } \\
\text { dioxide }\left(\mathrm{NO}_{2}\right)\end{array}$ & $\begin{array}{r}\text { Nasal epithelial } \\
\text { cells }\end{array}$ & $\begin{array}{r}\text { DNA strand breaks } \\
\text { (comet assay) } \\
\text { Micronucleus }\end{array}$ & $\begin{array}{l}+ \\
-\end{array}$ & $\begin{array}{r}\text { Koehler et } \\
\text { al., } 2010\end{array}$ \\
\hline
\end{tabular}

DEP: Diesel Exhaust Particles. A549 cells: human lung epithelial cell line. +Positive results. - Negative results. $\mathrm{PM}_{2.5}$ : Particulate Matter with aerodynamic diameter $\leq 2.5 \mu \mathrm{m}$. $\mathrm{PM}_{10}$ : Particulate Matter with aerodynamic diameter $\leq 10 \mu \mathrm{m}$.

Table 1. Genotoxic damage studies associated with air pollutants. 

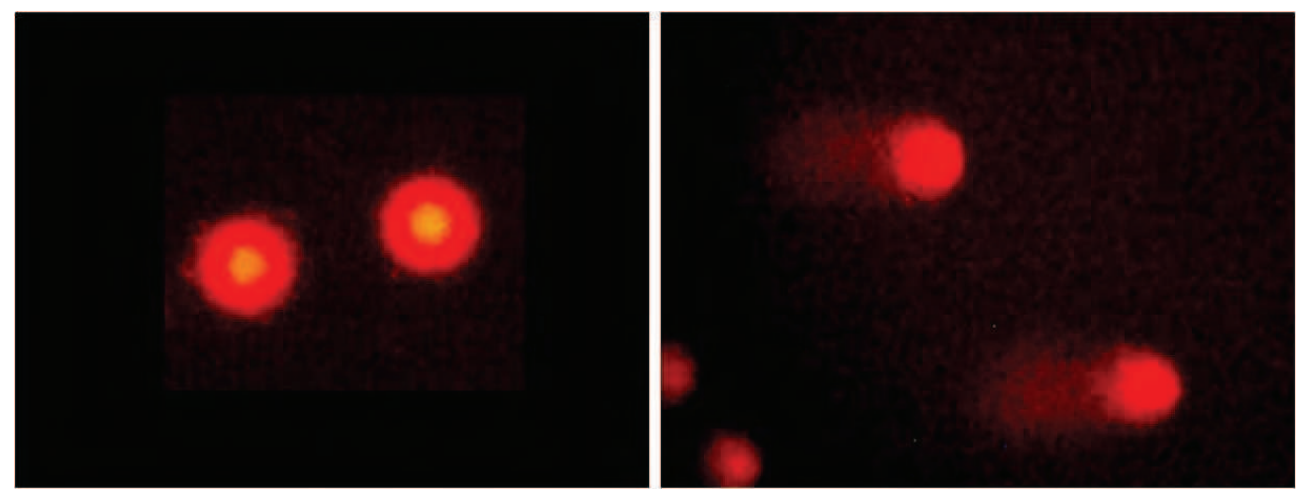

Fig. 7. Comet assay in nasal epithelial cells. Left: Undamaged Cells. Right: Damaged Cells (comets).

\subsection{Pulmonary fibrosis and atmospheric pollution}

Pulmonary fibrosis is the end result of a diverse group of lung disorders. Although there are multiple initiating agents for pulmonary fibrosis, including toxins, fibres/particles, autoimmune reactions, drugs and radiation, the etiology of the majority of cases of pulmonary fibrosis is unknown and these cases are referred to as Idiopathic Pulmonary Fibrosis (IPF). The harmful effects of environmental pollution on the respiratory system are undeniable. The combustion of fuels and its derivatives are the main cause for pollutant emission through engines and industrial plants (Zuurbier, et al., 2011). Chronic exposure to particulate matter, ozone and cigarette smoke can produce long-term effects on the lungs. This source of pollutants sets the lungs in a situation of constant aggression that result in a state of chronic inflammation, which could lead to pulmonary fibrosis (Churg \& Wright, 2002).

\subsubsection{Fibrotic lung reactions due to air pollution}

The etiology for lung's fibrotic reactions is still unknown and it has been proposed a variety of environmental stimuli, such as metals, cigarette smoke, drugs and infectious agents (Araya \& Nishimura, 2010). The degree of fibrosis will depend on the response of each individual, even with similar exposures, indicating that host genetic factors influence the fibrotic response of the patient (Westergren-Thorsson, et al., 2010).

Diesel exhaust particulate matter in polluted environments derived from internal combustion engines, increases the transcription of inflammatory cytokines and antimicrobial peptides, contributing to increased inflammatory response of airways in patients with chronic obstructive pulmonary diseases (COPD) (Nam, et al., 2006). This induces an oxidative state caused by lung macrophages that increase pulmonary responses and could result in irreversible lung fibrosis (Figure 8).

It has now been implicated the Transforming Growth Factor $\beta 1$ (TGF- $\beta 1$ ) as a key factor in the lung fibrotic response (Datta et al., 2011; Koli et al., 2008). The changes caused by TGF- $\beta 1$ could be observed in repeated injuries of the airways, as occurs in asthma, chronic obstructive pulmonary disease and pulmonary fibrosis (Araya \& Nishimura, 2010).

Exposure to cigarette smoke produces a large amount of reactive oxygen species and activates latent TGF- $\beta 1$. The inhalation of this smoke promotes the recruitment of macrophages and neutrophils that are important sources of reactive oxygen species and also 


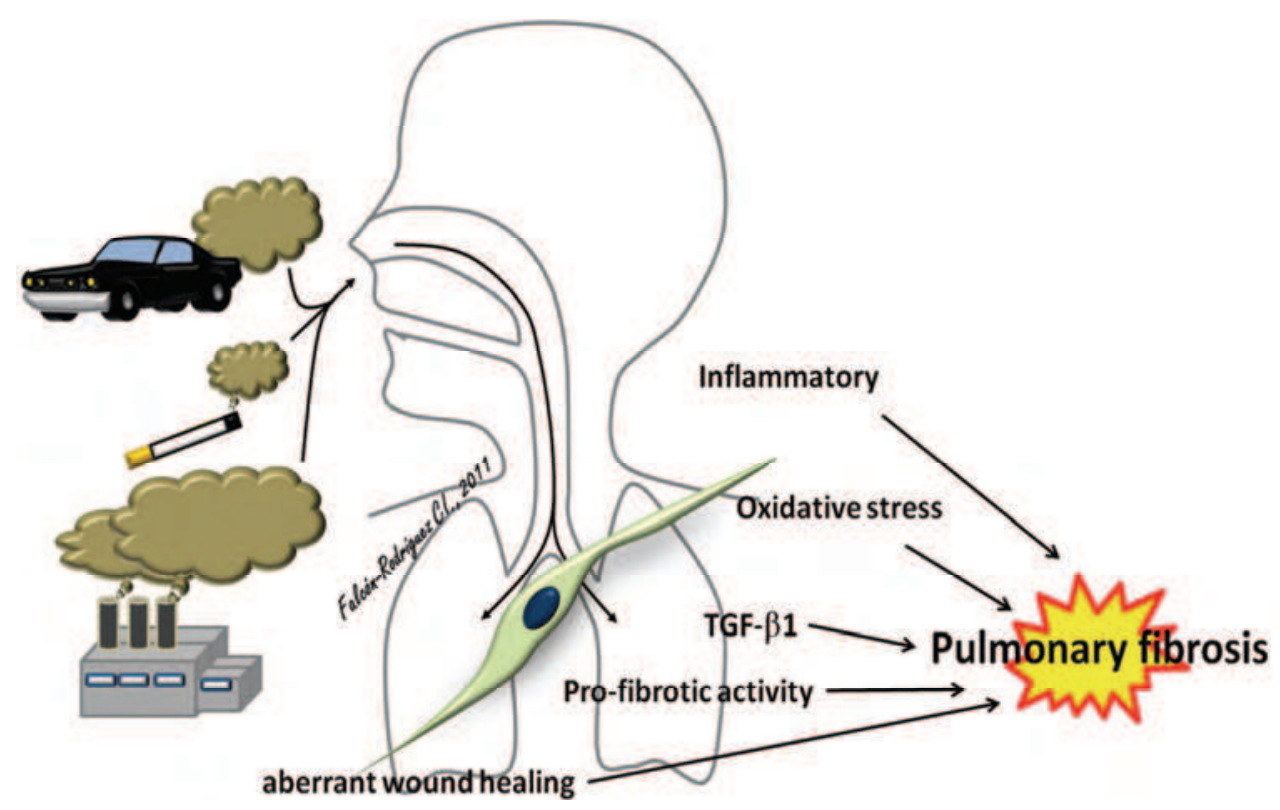

Fig. 8. Environmental pollution from various sources, such as transition metals, particle exposure, noxious drugs, cigarette smoke, induces repetitive cellular injury and inflammation. This leaves the tissue susceptible to increased TGF- $\beta 1$, inflammation, profibrotic signals and aberrant wound healing, all of which may contribute to the progression of pulmonary fibrosis.

contribute to activate TGF- $\beta 1$ (Westergren-Thorsson, et al., 2010). On the other hand, TGF- $\beta 1$ induces transdifferentiation of fibroblasts to myofibroblasts and perpetuates the fibrogenic process, also providing a protective effect against myofibroblasts apoptosis, which are not removed once the lung lesions healed (Song et al., 2011).

Asbestos can induce lung fibrosis in occupational and experimental exposures, (Ross and Murray.2004; Dai \& Churg, 2001). Mineral dusts can directly induce fibrosis in the airway wall, and this has been studied in vivo. Coexposures to cigarette smoke or ozone increase the fibrogenic effect of mineral dusts (Churg \& Wright, 2002; Churg et al., 1996). Asbestosis and mineral dusts exposure increase the gene expression of profibrotic factors: TGF- $\beta 1$ and platelet derived growth factor (PDGF) that also increases procollagen. These changes may explain fibrosis progression (Churg and Wright, 2002; Churg et al., 1999). There is also human evidence of small airway remodeling in chronic exposure to high levels of particulate air pollution (Churg et al., 2003).

Oxidative stress, as a consequence of an inflammatory stimulus such as air pollution, plays a critical role in the pathogenesis of IPF (Park et al., 2009). Fibrotic stimuli of unknown origin are thought to create an imbalance between oxidant production and antioxidant protection, resulting in the accumulation of reactive oxygen species (ROS) (Rahman et al., 1999). The precise pathways leading from injury to fibrosis are not well established, but oxidants may contribute to the production of profibrotic factors such as TGF $\beta$, and oxidized proteins have been reported in human subjects with IPF. In addition, some studies have reported 
that various antioxidant enzyme systems protect against lung fibrosis (Gao et al., 2008; Khang et al., 2003).

\subsection{Chronic obstructive pulmonary disease (COPD)}

Chronic Obstructive Pulmonary Disease (COPD) is a slowly progressive condition characterized by airflow limitation which is usually reversible (MacNee, 2007). Although smoking habit is the main factor associated with COPD, air pollution has been implicated in its pathogenesis, and there is enough evidence to support the association between air pollution and COPD exacerbations and worsening of those with pre-existing COPD. Particulate Matter (PM), Nitrogen Oxides (NOx) are associated with its development (Salvi \& Barnes, 2009).

Some of the observed changes are the increase in the presence of goblet cells (mucous metaplasia) as well as submucose glands hyperplasia. This increase in mucus production will result in reduced mucocliliary clearance. Emphysema, the enlargement and destruction of the alveolar spaces, is also part of this entity, because the decrease in the elastic recoil of the lung the air is trapped in the alveoli. Small airways are very important components in this entity. The changes, such as inflammation and fibrosis modify the prognosis: the greater the damage the poorer the prognosis.

The main participant in the progression of the bronchial damage is the inflammatory response. The epithelial cells generate this response when they are exposed to air pollutants or other irritants such as cigarette smoke, then a variety of pro-inflammatory, pro-fibrotic and mitotic factors are liberated. These factors increase endothelial permeability; activate macrophages, CD8+ Lymphocytes, and neutrophils. These cells produce more inflammatory factors, which, in chronic exposure inflammation leads to airway remodeling. (Figure 9) (Roth, 2008).

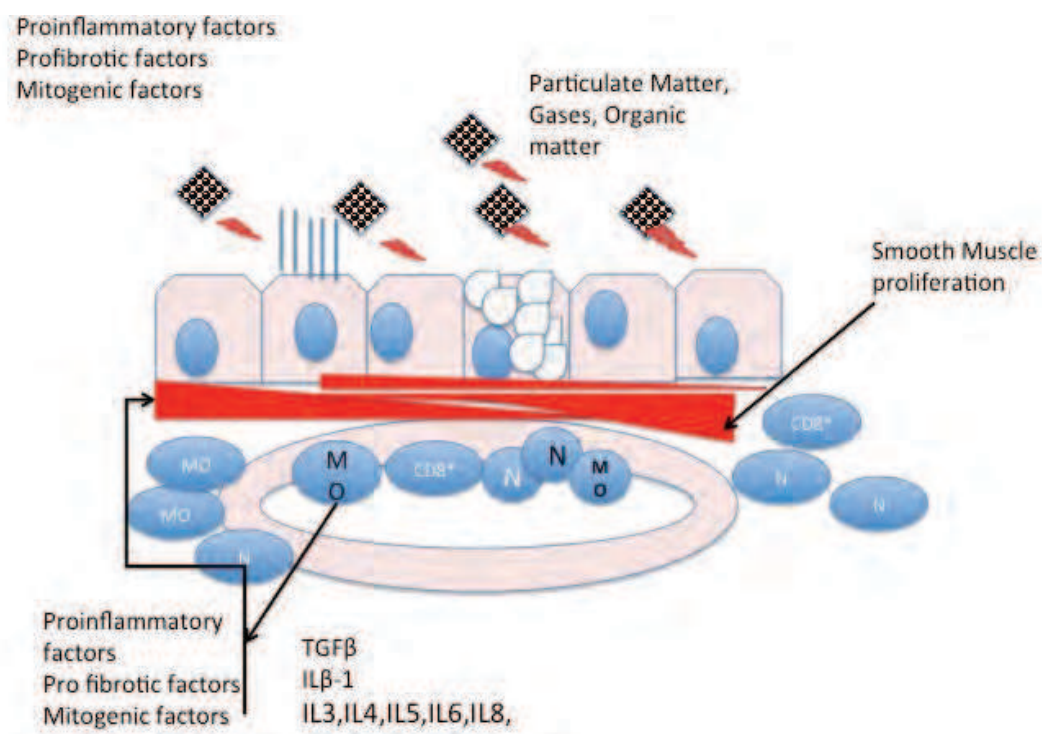

Fig. 9. The respiratory epithelium produces proinflammatory factors that will activate macrophages (MO), will increase neutrophil (N) and CD8* lymphocytes migration (CD8+). Also, smooth muscle proliferation is observed, as well as an alteration of the extracellular matrix. 
Remodeling includes smooth muscle and fibroblast proliferation, synthesis of extracellular matrix (MMPs), decrease in proteases synthesis and increase in gelatinases. The sum of all these events will maintain the obstruction observed in these patients.

\section{Conclusion}

Further studies are needed to assess the impact of atmospheric pollution in the development of respiratory diseases, and to explore new therapeutic approaches to reverse the progression of the chronic changes that currently are observed in asthma, COPD, fibrosis and cancer.

\section{Perspectives}

More information about the differences in the response to air pollutants is needs, as well as the possible treatments, if any of the biomarkers is found. This drives us to the need for more specific biomarkers to identify the severity of the inflammation, or the type of inflammation. Because air Pollution is a complex mixture of organic and inorganic elements, more detailed information about specific characteristics of each pollutant response would be very helpful.

The lung has its own responses and support for more research in this field of interest, must be encouraged.

\section{Acknowledgements}

Authors thank to Veronica Rodriguez-Mata for her technical work in the technical work for the histological preparations.

\section{References}

Abbas, I.; Saint-Georges; F.; Billet, S.; Verdin, A.; Mulliez, P.; Shirali, P. \& Garçon, G. (2009). Air Pollution Particulate Matter (PM 2.5)-Induced Gene Expression of Volatile Organic Compound and/or Polycyclic Aromatic Hydrocarbon-metabolizing Enzymes in an In Vitro Coculture Lung Model. Toxicology in Vitro, Vol.23, No.1, (February 2009), pp. 37-46, ISSN 0887-2333

Alavanja, M.C.R. (2002). Biologic Damage Resulting from Exposure to Tobacco Smoke and from Radon: Implication for Preventive Interventions. Oncogene, Vol.21, No.48, (October 2002), pp.7365 - 7375, ISSN 0950-9232

Alexis, N.E.; Lay J.C.; Zeman, K.; Bennet, W.E; Peden, D.B.; Soukup, J.M.; Devlin, R.B. \& Becker, S. (2006). Biological material on inhaled coarse fraction particulate matter activates airway phagocytes in vivo on healthy volunteers. Journal of Allergy Clinical Immunology, Vol.117, No. pp. 1367-1373 ISSN 00916749

Al-Zoughool, M.\& Krewski, D. (2009). Health Effects of Radon: A Review of the Literature. International Journal Radiation Biology, Vol. 85, No. 1, (2009),pp. 57-69 ISSN 0955-3002

Anwar-Mohamed, A.; Elbekai, R.H. \& El-Kadi, A.O.S. (2009) Regulation of CYP1A1 by heavy metals and consequences for drug metabolism. Expert Opinion on Drug Metabolism \& Toxicology, Vol.5, No.5, (May 2009), pp. 501-521, ISSN 1742-5255

Araya, J. \& Nishimura, S. L. (2010). Fibrogenic reactions in lung disease. Annual Review of Pathology, No.5, pp. 77-98, ISSN: 1553-4014, 
Atash, F. (2007). The deterioration of urban environments in developing countries: Mitigating the air pollution crisis in Theran, Iran. Cities, Vol.24, No.6, (February 2007), pp. 339 - 409, ISSN 0264-2751

Auten, R.L.; Potts, E.N.; Mason, S.N.; Fischer, B.; Huang, Y. \& Foster, W.M. (2009). Maternal Exposure to Particulate Matter Increases Postnatal Ozone-induced Airway Hyper reactivity in Juvenile Mice. American Journal Respiratory Critical Care Medicine, Vol.180, No.12, (December 2009), pp. 1218-1226, ISSN 1073-449X

Barnes, T.C., Spiller, D.G., Anderson, M.E; Edwards, S..W., Moots, R.J.(2011). Endothelial activation and apoptosis mediated by neutrophil-dependent interleukin 6 transsignaling: a novel target for systemic sclerosis. Annals of the Rheumatic Diseases (February, 2011) Vol. 70, No. 2, pp. 366-372. ISNN 1468-2060

Ben A.; Hutchinson E.; Unwin, J.; \& Fletcher, T. Lung Cancer Risk after Exposure to Polycyclic Aromatic Hydrocarbons: A Review and Meta-Analysis. Environmental Health Perspectives, Vol.112, No. 9, (January 2004), pp. 970-78, ISSN: 0091-6765

Bernstein, J.; Neil, A.; Barnes, Ch.; Bernstein, L.; Bernstein, J.; Nel, A.; Peden, D.; Diaz S.D.; Tarlo, S. \& Williams, B. (2004). Health effects of air pollution. Environmental and Occupational Respiratory Disorders, Vol.114, No. 5 (August 2004), pp. 1116 -1123

Beyersmann, D. \& Hartwig, A. (2008). Carcinogenic Metal Compounds: Recent Insight into Molecular and Cellular Mechanisms. Archives of Toxicology, Vol. 82, (May 2008), pp. 493-512, ISSN 0340-5761

Bissett, R.J. \& McLaughlin J.R. Radon. Chronic Disease Canada, Vol.29, Suppl 1, (2010), pp.3850, ISSN 0228-8699

Born, S.L.; Caudill D.; Fliter K.L. \& Purdon M.P. (2002). Identification of the Cytochromes P450 that Catalyze Coumarin 3,4-epoxidation and 3-hydroxylation. Drug Metabolism and Disposition, Vol.30, No.5, (May 2002), pp. 483-487, ISSN 0090-9556

Bostrom, CE.; Gerde, P.; Hanberg, A.; Jernstrom, B.; Johansson, C.; Kyrklund, T.; Rannung, A.; Tornqvist, M.; Victorin, K. \& Westerholm R. (2002). Cancer Risk Assessment, Indicators, and Guidelines for Polycyclic Aromatic Hydrocarbons in the Ambient Air. Environmental Health Perspectives, Vol.110, (Jun 2002), pp.451-488, ISSN 0091-6765

Bulut, Y.; Shimada, K.; Wong, M.H; Chen, S; Gray, P; Alsabeh, R.; Doherty, T.M.; Crother, T.R; \& Arditi, M.(2009). Chlamydial heat shock protein 60 induces acute pulmonary inflammation in mice via the Toll-like receptor 4- and MyD88-dependent pathway. Infection and Immunity, Vol. 77, No. 7, (April, 2009) pp. 2683-2690. ISSN:0019-9567

Calderon-Garcidueñas, L.; Vincent, R; Mora-Tiscareño, A; Franco-Lira, M; HenriquezRoldan, C; Barragan-Mejia, G; Garrido-Garcia, L; Camacho-Reyes, L; ValenciaSalazar, G; Paredes, R; Romero, L.; Osnaya, H.; Villareal-Calderon, R; TorresJardon, R; Hazucha, M.J; \& Reed, W. (2007). Elevated plasma endothelin-1 and pulmonary arterial pressure in children exposed to air pollution. Environmental Health Perspectives, (August, 2007) Vol. 115, No. 8, pp. 1248-1253. ISSN:1552-9924

Cao, J.; Chunxue Yang,; Jianxin Li,; Renjie Chen,; Bingheng Chen,; Dongfeng Gu \& Haidong Kan J. (2011). Association Between Long-Term Exposure to Outdoor Air Pollution and Mortality in China: A Cohort Study. Journal of Hazardous Materials . Vol.186, No. 2-3, (January 2011), pp.1594-1600. ISSN: 0304-3894

Cardoso, W.V. \& Lü, J. (2006). Regulation of Early Lung Morphogenesis: Questions, Facts and Controversies. Development, Vol.133, No.9 (May 2006),pp. 1611-1624, ISSN 0950-1991 
Carlson, G.R. (2008). Critical Appraisal of the Expression of Cytochrome P450 Enzymes in Human Lung and Evaluation of the Possibility that such Expression Provides Evidence of Potential Styrene Tumorigenicity in Humans. Toxicology, Vol.254, No.12, (December 2008), pp. 1-10, ISSN 030-483X

Castell, J.V.; Donato, M.T. \& Gomez-Lechon, J.M. (2005). Metabolism and Bioactivation of Toxicants in the Lung. The In Vitro Cellular Approach. Experimental and Toxicologic Pathology, Vol.57, (July 2005), pp.189-204, ISSN 0940-2993

Chang, H.; Chang, L.W.; Cheng, Y.H.; Tsai, W.T.; Tsai, M.X. \& Lin, P.P. (2006). Preferential Induction of CYP1A1 and CYP1B1 in CCSP-Positive Cells. Toxicological Sciences, Vol.89, No.1, (January 2006), pp. 205-213, ISSN 1096-6080.

Chen, F.; Jackson, H. \& Bina, WF. (2009). Lung Adenocarcinoma Incidence Rates and Their Relation to Motor Vehicle Density. Cancer Epidemiology Biomarkers Prevention. Vol.18, No.3, (March 2009), 760-764, ISSN 1055-9965

Choudhary, D.; Jansson, I.; Stoilov, I.; Sarfarazi, M. \& Schenkman J.B. (2005). Expression Patterns of Mouse and Human CYP Orthologs (Families 1-4) During Development and in Different Adult Tissues. Archives of Biochemistry and Biophysics, Vol.436, No.1, (April 2005), pp. 50-61, ISSN 0003-9861

Churg, A. \& Wright, J.L. (2002). Airway wall remodeling induced by occupational mineral dusts and air pollutant particles. Chest ; Vol.122, No.6 suppl (December 2002), pp. 306S-309S, ISSN 0012-3692

Churg, A.; Brauer M. \& Keeling, B. (1996). Ozone enhances the uptake of mineral particles by tracheobronchial epithelial cells in organ culture. American Journal of Respiratory and Critical Care of Medicine, No.153, No.4, pp.1230-1234, ISSN 1073-449X

Churg, A.; Brauer, M.; Avila-Casado, M.C.; Fortoul, T.I. \& Wright, J.L. (2003). Chronic exposure to high levels of particulate air pollution and small airway eemodeling. EnvironmentalHealth Perspectives, Vol.111, No.5, (May 2003) pp. 714-718, ISSN: 0091-6765.

Churg, A.; Gilks, B. \& Dai, J. (1999). Induction of fibrogenic mediators by fine and ultrafine titanium dioxide in rat tracheal explants. American Journal of Physiology, Vol.277, No. 5 pt 1, pp. L975-L982, ISSN: 0363-6143;

Dai, J. \& Churg, A. (2001). Relationship of fiber surface iron and active oxygen species to expression of procollagen, PDGF-A, and TGF 1 in tracheal explants exposed to amosite asbestos. American Journal of Respiratory Cell and Molecular Biology, Vol.24, No.4, (April 2001)pp. 427-435, ISSN: 1535-4989

Datta, A.; Scotton, C. J. \& Chambers, R. C. (2011). Novel Therapeutic Approaches for Pulmonary Fibrosis. British Journal of Pharmacology. Epub ahead of print, ISSN 0007-1188.

Davis, C.W. \& Dicker, B.E. (2008). Regulated Airway Goblet Cell Mucin Secretion. Annual Review of Physiology, Vol.70, (March 2008), pp.487-512, ISSN 0066-4278

Deb, S. \& Bandiera, S.M. (2010). Characterization of a New Cytochrome P450 Enzyme, CYP2S1, in Rats: Its Regulation by Aryl Hydrocarbon Receptor Agonists. Toxicology, Vol.267, No.1-3, (January 2010), pp. 91-98, ISSN 0300-483X

Dockery, DW.; Pope, CA; Xu, X.; Spengler, JD.; Ware, JH,; Fay, ME,; Ferris, BG. Jr. \& Speizer, FE. (1993). An Association Between Air Pollution and Mortality in Six U.S. Cities. New England Journal Medicine, Vol.329, (December 1993), pp.1753-9, ISSN 0028-4793 
Donaldson, K; Mills, N; MacNee, W.; Robinson, S; \& Newby, D. (2005). Role of inflammation in cardiopulmonary health effects of PM. Toxicology and Applied Pharmacology, Vol. 207, No. 2 (Sept, 1, 2005) pp. 483-488. ISSN:0041-008X

Dybdahl, M.; Risom, L.; Bornholdt, J.; Autrup, H.; Loft, S. \& Wallin, H. (2004). Inflammatory and Genotoxic Effects of Diesel Particles In Vitro and In Vivo. Mutation Research, Vol.562, No.1-2, (August 2004), pp.119-131, ISSN 1383-5718

Ekici, A.; Ekici, M., Kurtipek, E., Akin, A., Arsian, M., Kara, T., Apaydin, Z., Demir, S. (2005) Obstructive airway diseases in women exposed to biomass smoke. Environmental Research, Vol. 99, No.1, (September, 2005) pp. 93-98. ISSN:0013-935

Feng, Z.; Hu, WW.; Rom, WN.; Costa, M. \& Tang, MS. (2003). Chromium(VI) exposure enhances polycyclic aromatic hydrocarbon DNA binding at the p53 gene in human lung cells. Carcinogenesis, Vol.24, No.4, (April 2003), pp.771-778, ISSN 0143-3334.

Finlayson-Pitts, B. J. \& Pitts, J. N. (1997). Tropospheric air pollution: ozone, airborne toxics, polycyclic aromatic hydrocarbons and particles. Science, Vol.276, No. 5315, (May 1997), pp.1045-1052, ISSN 0036-8075

Finlayson-Pitts, B.J. \& Pitts, J.N. (2000). Chemistry of the Upper and Lower Atmosphere, Academic Press, San Diego, California, xxii+969 pp., ISBN 0-12-257060xMills, N.L. Donaldson, D., Hadoke, P.W., Boon, N.A., MacNee, W., Cassee, F.R., Sandström, T., Blomberg, A. \& Newby D.E. (2009). Adverse cardiovascular effects of air pollution. Nature Clinical Practice Cardiovascular Medicine, Vol. 6, No.1, (November, 2009), pp. 36-44, ISSN: 1759-5002

Forrester, K.; Ambs, S.; Lupold, SE.; Kapust, RB.; Spillare. EP.; Weinberg, WC.; Felley-Bosco, E.; Wang, XW.; Geller, DA.;Tzeng, E. \& Billar, TR. (1996). Harris CC. Nitric OxideInduced p53 Accumulation and Regulation of Inducible Nitric Oxide Synthase Expression by Wild-type p53. Proceedings of the National Academy Science USA. Vol. 93, (March1996), pp. 2442-2447, ISSN 0027-8424

Fortoul, T.I.; Rodriguez-Lara, V.; Lopez-Valdez, N. \& Falcon-Rodriguez, C.I. (2010). Sistema Respiratorio, In: Histologia y Biologia Celular. T.I. Fortoul van der Goes, (Ed.), 187195, McGraw-Hill, ISBN: 978-607-15-0340-4, China

Fortoul, T.I.; Rojas-Lemus, M.; Avila-Casado M.C.; Rodriguez-Lara V.; Montaño, L.F.; Muñoz-Comonfort, A. \& Lopez-Zepeda, S. (2010), Endogenous Antioxidants and Nasal Human Epithelium Response to Air Pollutants: Genotoxic and Inmmunocytochemical Evaluation. Journal of Applied Toxicology, Vol.30, No.7, (October, 2010), pp.661-665, ISSN 0260-437X

Fujimoto, H.; Sasaki, J.; Matsumoto, M.; Suga, M.; Ando, Y.; Iggo, R.; Tuda, M.; Saya, H. \& Anas, M. (1998). Significant Correlation of Nitric Oxide Synthase Activity and p53 Gene Mutation in Stage I Lung Adenocarcinoma. Japanese Journal of Cancer Research.Vol. 89, (July 1998), pp. 696-702, ISSN 0910-5050

Gabay, C., \& Kushner, I. (1999) Acute-phase proteins and other systemic responses to inflammation. New England Journal of Medicine, (February, 11, 1999) Vol. 340, No.6, pp.448-454. ISSN:0028-4793

Gao, F.; Kinnula, V.L.; Myllarniemi, M. \& Oury, T.D. (2008). Extracellular superoxide dismutase in pulmonary fibrosis. Antioxidants \&. Redox Signal, Vol.10, No. 2, (February 2008), pp.343-54, ISSN: 1523-0864

Gern, J.E. (2010). The Urban Environment and Childhood Asthma Study. Journal of Allergy and Clinical Immunology, Vol.125, No.3, (March 2010), pp. 545-549, ISSN 0091-6749 
Gutierrez-Castillo, M.E.; Roubicek, D.A.; Cebrian-García M.E.; Vizcaya-Ruiz, A.D.; SordoCedeno, M. \& Ostrosky-Wegman, P. (2006). Effect of Chemical Composition on the Induction of DNA Damage by Urban Airbone Particulate Matter. Environmental and Molecular Mutagenesis, Vol.47, No.3, (April 2006), pp. 199-211, ISSN 0893-6692

Halle, S.; Dujardin, H.; Bakocevic, N.; Fleige, H.; Danzer, H.; Willenzon, S.; Suezer, Y.; Hammerling, G.; Garbi, N.; Sutter, G.; Worbs, T. \& Forster, R. (2009). Induced bronchus-associated lymphoid tissue serves as a general priming site for $\mathrm{T}$ cells and is maintained by dendritic cells. Journal of Experimental Medicine, Vol.206, No.12, (November 2009), pp. 2593-2601, ISSN: 0022-1007

Harley, NH.; Chittaporn, P.; Heikkinen, MSA.; Meyers, OA. \& Robbins, ES. (2008). Radon Carcinogenesis: Risk Data and Cellular Hits. Radiation Protection Dosimetry. Vol.130, No.1, (June 2008), pp.107-109, ISSN 0144-8420

Hetland, R.B; Cassee, F.R; Lag, M., Refsnes, M; Dybing, E; \& Schwaze, P.E. (2005) Cytokine release from alveolar macrophages exposed to ambient particulate matter: heterogeneity in relation to size, city and season. Particle and Fibre Toxicology, Vol. 17, No.2, (August, 2005) pp. 1-15, SSN:1743-8977

Hildebrandt, K; Ruckerl, R.; Koeening, W.; Schneider, A.; Pitz, M.; Heinrich, J; Marder, V.; Frampton, M.; Oberdorster, G; Wichmann, G; \& Peters, A. (2009). Short-term effects of air pollution: a panel study of blood markers in patients with chronic pulmonary disease. Particle and Fibre Toxicology (September, 2009). Vol. 26, No.25, pp. 1-13. ISSN:1743-8977

Holgate, S.T. (2008). The Airway Epithelium is Central to the Pathogenesis of Asthma. Allergology International, Vol.57, No.1, (March 2008), pp. 1-10, ISSN 1323-8930

Ioannides, C. (2008). Cytochromes P450. Role in the metabolism and toxicity of drugs and others xenobiotics, RSC Publishing, ISBN: 978-0-85404-274-6, Cambrigde, UK

Jenkins, DC,; Charles, IG.; Thomsen, LL.; Moss, DW.; Holmes, LS.; Baylis, SA.; Rhodes, P.; Westmore, K.; Emson, PC. \& Moncada, S. (1995). Roles of Nitric Oxide in Tumor Growth. Proceedings of the National Academy Science USA, Vol.92, (May 1995), pp.4392-6, ISSN 0027-8424

Kang, S.K.; Rabbani, Z.N.; Folz, R.J.; Golson, M.L.; Huang, H.; Samulski; T.S.; Dewhirst, M.W.; Anscher, M.S. \& Vujaskovic, Z. (2003). Overexpression of extracellular superoxide dismutase protects mice from radiation-induced lung injury. International Journal of Radiation Oncology Biology Physics, Vol.15, No. 57, (November 2003), pp. 1056-66, ISSN: 0360-3016.

Katavolos, P.; Ackerley, C.A.; Viel, L.; Clark, M.E.; Wen, X. \& Bienzle, D. (2009). Clara Cell Secretory Protein Is Reduced in Equine Recurrent Airway Obstruction. Veterinary Pathology, Vol.46, No.4, (July 2009), pp. 604-613, ISSN 0300-9858

Kawamata, N.; Xu, B.; Nishijima, H.; Aoyama, K.; Kusumoto, M.; Takeuchi, T.; Tei, Ch.; Michie, A. \& Matsuyama, T. (2009). Expression of endothelia and lymphocyte adhesion molecules in bronchus-associated lymphoid tissue (BALT) in adult human lung. Respiratory Research, Vol.10, No.97, (October 2009), pp. 1-11, ISSN: 1465-9921

Koehler, C.; Ginzkey, C.; Friehs, G.; Hackenberg, S.; Froelich, K.; Scherzed, A.; Burghartz, M.; Kessler, M. \& Kleinsasser, N. (2010). Aspects of Nitrogen Dioxide Toxicity in Environmental Urban Concentrations in Human Nasal Epithelium. Toxicology and Applied Pharmacology, Vol.245, No.2, (June 2010), pp. 219-225, ISSN 0041-008X 
Koli, K.; Myllarniemi, M.; Keski-Oja, J. \& Kinnula, V.L. (2008). Transforming growth factor-1 activation in the lung: focus on fibrosis and reactive oxygen species. Antioxidants \& Redox Signal, Vol.10, No.2, (February 2008), pp. 333-42, ISSN: 1523-0864

Liaw, YP.; Ting, TF.; Ho, CC. \& Chiou, ZY. (2010). Cell Type Specificity of Lung Cancer Associated with Nitric Oxide. Science of the Total Environment, Vol.408, No.21, (October 2010), pp.4931-4, ISSN 0048-9697

López-Cima, MF.; García-Pérez, J.; Pérez-Gómez, B.; Aragonés, N.; López-Abente G.; Tardón, A. \& Pollán, M. (2011). Lung Cancer Risk and Pollution in an Industrial Region of Northern Spain: a Hospital-based Case-Control Study. International Journal Health Geographics, Vol.25, No.10, (January 2011), pp.10-23, ISSN 1572-9893

MacNee, W. (2007) Pathogenesis of Chronic Obstructive Pulmonary disease. Clinics in Chest Medicine, Vol.2, No.4, (November 2005), pp. 479-513, ISSN: 0272-5231

Mates, JM. ; Segura, JA.; Alonso, FJ. \& Marquez, J. (2010). Roles of Dioxins and Heavy Metals in Cancer and Neurological Diseases Using ROS-Mediated Mechanisms. Free Radical Biology \& Medicine, Vol. 49, (November 2010), pp. 1328-1341. ISSN: 0891-5849

Mills, N.L; Amin, N; Robinson, S.D; Anand, A; Davies, J; Patel, D; de la Fuente, J.M; Cassee, F.R; Boon, R.A; MacNee, W; Millar, A.M; Donaldson, K. \& Newby D.E. (2006). Do Inhaled Carbon Nanoparticles Translocate Directly into the Circulation in Humans? American Journal of Respiratory and Critical Care Medicine Vol. 173, No. 4, (February, 2006) pp. 426-431, ISSN 1535-4970

Molina, JR.; Yang, P.; Cassivi, SD.; Schild, SE. \& Adjei, AA. (2008). Non-Small Cell Lung Cancer: Epidemiology, Risk Factors, Treatment, and Survivorship. Mayo Clinic Proceedings, Vol.83, No.5, (May 2008), pp.584-594, ISSN 0025-6196

Moller, P. (2005). Genotoxicity of Environmental Agents Assessed by the Alkaline Comet Assay. Basic E Clinical Pharmacology and Toxicology, Vol.96, Suppl1, (January 2005), pp.1-42, ISSN I742-7835

Morris, J.B. \& Buckpitt, A.R. (2009). Upper Respiratory Tract Uptake of Naphthalene. Toxicological Sciences, Vol.111, No.2, (October 2009), pp. 383-391, ISSN 1096-6080

Mortimer, K.; Neugebauer, R.; Lurmann, F.; Alcorn, S.; Balmes, J. \& Tager, I. (2008). Air Pollution and Pulmonary Function in Asthmatic Children: Effects of Prenatal and Lifetime Exposures. Epidemiology, Vol.19, No.4, (July 2008), pp. 550-562, ISSN 1044-3983

Mussali-Galante, P. \& Fortoul, T.I. (2008). Atmospheric pollution, In: Environmental Research Progress, F.P. Maes, (Ed.), 147-160, Nova Science Publishers, ISBN: 978-1-60456-0800 , New York, USA

Næss Øyvind; Per Nafstad; Geir Aamodt; Bjørgulf Claussen \& Pa Rosland. (2007). Relation Between Concentration of Air Pollution and Cause-Specific Mortality:Four-Year Exposures to Nitrogen Dioxide and Particulate Matter Pollutants in 470 Neighborhoods in Oslo, Norway. American Journal of Epidemiology. Vol.165, No.4, (February 2007), pp. 435-443, ISSN 0002-9262

Nam, H. Y., Ahn, E. K., Kim, H. J., Lim, Y., Lee, C. B., Lee, K. Y. \& Vallyathan,V. (2006). Diesel exhaust particles increase IL-1beta-induced human beta-defensin expression via NF-kappaB-mediated pathway in human lung epithelial cells. Particle \& Fibre Toxicology, Vol.3, No.9 (May 2006) (available on line), ISSN: 17438977

Nemmar, A; Vanbilloen, H; Hoylaerts, M.F; Hoet, P.H; Verbruggen, A.; \& Nemery, B. (2002). Passage of intratracheally instilled ultrafine particles from the lung into the 
systemic circulation in hamster. American Journal of Respiratory and Critical Care Medicine, Vol. 165, No.12, (June, 2002) pp. 1671-1672, ISSN 1535-4970

Olive, P.L.; Durand, R.E.; Banath, J.P. \& Johnston, P.J. (2001). Analysis of DNA Damage in Individual Cells. Methods in Cell Biology, Vol.64, (2001), pp.235- 249, ISSN 0091-679X

Olivieri, D. \& Scoditti E. (2005). Impact of Environmental Factors on Lung Defences. European Respiratory Review, Vol.14, No.95, (December 2005), pp. 51-56, ISSN 0905-9180

Park, H.S.; Kim, S.R. \& Lee, Y.L. (2009). Impact of oxidative stress on lung diseases. Respirology, Vol.14, No.1, (January 2009), pp. 27- 38, ISSN: 13237799

Parker,D., \& Prince, A.(2011) Innate Immunity in the Respiratory Epithelium. American Journal of Respiratory and Critical Care Medicine, ( Februarry, 2011)(Epublish ahead of print) ISSN:1044-1549

Pavek, P. \& Dvorak, Z. (2008). Xenobiotic-Induced Transcriptional Regulation of Xenobiotic Metabolizing Enzymes of the Cytochrome P450 Superfamily in Human Extrahepatic Tissues. Current Drug Metabolism, Vol.9, No.2, (February 2008), pp. 129-143, ISSN 1389-2002

Penn, A.L.; Rouse, R.L.; Horohov, D.W.; Kearney, M.T.; Paulsen, D.B. \& Lomax, L. (2007). In Utero Exposure to Environmental Tobacco Smoke Potentiates Adult Responses to Allergen in BALB/c Mice. Environmental Health Perspectives, Vol.115, No.4, (April 2007), pp. 548-555, ISSN 0091-6765

Perez-Padilla, R.; Schilmann, A. \& Riojas-Rodriguez, H. (2010). Respiratory Health Effects of Indoor Air Pollution. International Journal Tuberculosis Lung Disease, Vol. 14, No. 9, (September 2010), pp. 1079-1086, ISSN 1081-1206

Pons, F.; Haag, M.; Corcos, L.; Bonnet, P.; Guillouzo, A.; Lugnier, A. \& Frossard, N. (2000). Inhalation of Toluene Diisocyanate Affects Cytochrome P4502B1 Expression in Rat Lung. Archives of Toxicology, Vol.74, No.7, (September 2000), pp. 397-403, ISSN 0340-5761

Pope, CA.; Burnett, RT.; Thun, MJ.; Calle, EE.; Krewski, D.; Ito, K. \& Thurston, GD. (2002). Lung Cancer, Cardiopulmonary Mortality, and Long-term Exposure to Fine Particulate Air Pollution. Journal of the American Medical Association, Vol. 287, No. 9, (March 2002), pp. 1132-1141, ISSN 0098-7484

Pope, CA.; Thun, MJ.; Namboodiri, MM.; Dockery, DW.; Evans, JS.; Speizer, FE. \& Heath, CW. (1995). Particulate Air Pollution as a Predictor of Mortality in a Prospective Study of U.S. Adults. American Journal Respiratory Critcal Care Medicine, 151, (March 1995), pp.669-74, ISSN 1073-449X

Raaschou-Nielson, O.; Bak, H.; Sorensen, M.; Jensen, SS.; Ketzel, M.; Huiberg, M.; Schnohr, P.; Tjonneland, A. Overvad, K. \& Loft, S. (2010). Air Pollution from Traffic and Risk for Lung Cancer in Three Danish Cohorts. Cancer Epidemiology Biomarkers and Prevention. Vol. 19, No.5, (May 2010), pp. 1284-91, ISSN1055-9965

Rahman, I.; Skwarska, E.; Henry, M.; Davis, M.; O'Connor, C.M.; FitzGerald, M.X.; Greening, A. \& MacNee, W. (1999). Systemic and pulmonary oxidative stress in idiopathic pulmonary fibrosis. Free Radical Biology \& Medicine, Vol.27, No.1-2, (July 1999), pp. 60-8, ISSN: 0891-5849.

Randall, T.D. (2010). Bronchus-associated lymphoid tissue (BALT) structure and function. Advances in Immunology, No. 107, (November 2010), pp. 187-241, ISSN 0065-2776 
Raub, J.; MathieuNolf, M.; Hampson N. \& Thom S. (2000). Carbon monoxide poisoning - a public health perspective. Toxicology, Vol.145, No.1, (April 2000), pp 1- 14, ISSN 0300-483X

Rice, G.E., \& Bevilacqua, M.P. (1989) An inducible endothelial cell surface glycoprotein mediates melanoma adhesion. Science, (December,8, 1989) Vol .246, No. 4935, pp.1303-1306. ISSN:0193-4511

Risch, A. \& Plass, C. (2008). Lung Cancer Epigenetics and Genetics. International Journal of Cancer, Vol. 123, No. 1, (July 2008), pp. 1-7, ISSN 0020-7136

Risom, L.; Dybdahl, M.; Bornholdt, J.; Vogel, U.; Wallin, H.; Moller, P. \& Loft, S. (2003). Oxidative DNA Damage and Defence Gene Expression in the Mouse Lung after Short-Term Exposure to Diesel Exhaust Particles by Inhalation. Carcinogenesis, Vol.24, No.11, (November 2003), pp.1847-1852, ISSN 0143-3334

Rojas-Martinez, R.; Perez-Padilla, R.; Olaiz-Fernandez G.; Mendoza-Alvarado, L.; MorenoMacias, H.; Fortoul, T.; McDonell, W.; Loomis, D. \& Romieu, I. (2007). Lung Function Growth in Children With Long-term Exposure to Air Pollutants in Mexico City. American Journal of Respiratory and Critical Care of Medicine, No.176, pp. 377-384, ISSN 1073-449X

Rose, M.C. \& Voynow, J.A. (2006). Respiratory Tract Mucin Genes and Mucin Glycoproteins in Health and Disease. Physiological Reviews, Vol.86, No.1, (January 2006), pp. 245278, ISSN 0031-9333

Ross, M.H. \& Murray, J. (2004). Occupational Respiratory disease in mining. Occupational Medicine, Vol.54, No.5, pp. 304-310, ISSN: 0962-7480.

Roth, M. (2008) Pathogenesis of COPD. Part II. Inflammation in COPD. The International Journal of Tuberculosis and Lung Disease, Vol.12, No.4 (April 2008), pp. 375-380, ISSN 1027-3719

Roubicek, D.A.; Gutierrez-Castillo, M.; Sordo, M.; Cebrian-García M.E. \& OstroskyWegman, P. (2007). Micronuclei Induced by Airbone Particulate Matter from Mexico City. Mutation Research, Vol.631, No 1, (July 2007), pp.9-15, ISSN 1383-5718

Ruano-Ravina, A.; Faraldo-Valles, MJ. \& Barros-Dios, JM. (2009). Is there a Specific Mutation of p53 Gene Due to Radon Exposure? A Systematic Review. International Journal Radiation Biology. Vol.85, No. 7, pp.614-621, ISSN 0955-3002

Salnikow, K. \& Zhitkovich, A. (2008). Genetic and Epigenetic Mechanisms in Metal Carcinogenesis and Cocarcinogenesis: Nickel, Arsenic, and Chromium, Chemical Research Toxicology, Vol. 21, (January 2008), pp. 28-44, ISSN 0893-228X

Salvi, S.S., \& Barnes, P. (2009) Chronic Obstructive Pulmonary Disease in Non-smokers. The Lancet, Vol.374, No. 9691 (August 2009), pp. 733-743, ISSN 0140-6736

Sato, H.; Sone, H.; Sagai, M.; Suzuki, KT. \& Aoki, Y. (2000). Increase in Mutation Frequency in Lung of Big Blue(R) Rats by Exposure to Diesel Exhaust. Carcinogenesis, Vol.21, No.4, (April 2000), pp. 653-661, ISSN 0143-3334

Saura, M; Zaragoza, C; Bao, C.; Rodriguez-Puyol, M; \& Lowenstein, C.J. (2006). Stat3 mediates interleukin-6 [correction of interelukin-6] inhibition of human endothelial nitric-oxide synthase expression. Journal of Biological Chemistry, (October,1, 2006). Vol.281, No.40, pp. 30057-30062. ISSN: 1083-351X

Sawant, S.G.; Randers-Pherson, G.; Geard, CR.; Brenner, D.J. \& Hall EJ. (2001). The Bystander Effect in Radiation Oncogenesis: I. Transformation in C3H 10T1/2 Cells in vitro can be initiated in the Unirradiated Neighbors of Irradiated Cells. Radiation Research, Vol.155, No.3, (March 2001), pp. 397-401, ISSN 0033-7587 
Schikowski, T; Sugiri, D; Ranft, U; Gehring, U; Heinrich, J; Wichmann, H.E.; \& Kramer, U. (2005) Long-term air pollution exposure and living close to busy roads are associated with COPD in women. Respiratory Research, Vol. 22, No. 6 (December, 2005) pp. 152-161, ISSN:1465-9921

Schins, R.P; Lightbody, J.H; Borm, P.J; Shi, T; Donaldson, K.; \& Stone, V. (2004) Inflammatory effects of coarse and fine particulate matter in relation to chemical and biological constituents. Toxicology and Applied Pharmacology, Vol. 195, No. 1 (Feb, 2004) pp. 1-11. ISSN:0041-008X

Schwarze, P.E; Oyreyik, J; Lag, M; Refsnes, M.; Nafstad, P.; Hetland, R.B.; \& Dybing, E. (2006) Particulate matter properties and health effects: consistency of epidemiological and toxicological studies. Human and Experimental Toxicology, Vol. 25, No. 10 (October, 2006) pp.559-579. ISSN:0960-3271

Seagrave, J. (2008). Mechanisms and implications of air pollution particle associations with chemokines. Toxicology and Applied Pharmacology, (November, 1, 2008).Vol. 232, No. 3, pp. 469-477. ISSN: 1096-0333

Seagrave, J; McDonald, J.D; Bedrick, E; Edgerton, E.S; Gigliotti, A.P; Jansen, J.J; Ke, L.; Naeher, L.P; Seilkop, S.K; Zheng, M; \& Mauderly, J.L. (2006) Lung toxicity of ambient particulate matter from southeastern U.S. sites with different contributing sources: relationships between composition and effects. Environmental Health Perspectives, Vol. 114, No. 9, (September, 2006) pp. 1387-1393. ISSN:0091-6765

Sharma, A.K; Jensen, K.A; Rank, J; White, P.A; Lundstedt, S; Gagne, R; Jacobsen, N.R; Kristiansen, J; Vogel, U. \& Wallin, H. (2007). Genotoxicity, Inflammation and Physic-Chemical Properties of Fine Particle Samples from an Incineration Energy Plant and Urban Air. Mutation Research-Genetic Toxicology and Environmental Mutagenesis, Vol.633, No.2, (October 2007), pp. 95-111, ISSN 1385-5718

Shoenfelt, J.; Mitkus, R. J.; Zeisler, R.; Spatz, R. O.; Powell, J.; Fenton, M. J.; Squibb, K. A.; Medvedev, A. E. (2009). Involvement of TLR2 and TLR4 in inflammatory immune responses induced by fine and coarse ambient air particulate matter. Journal of Leukocyte Biology, Vol. 86 No.2, (August, 2009) pp. 303-312. ISSN:0741-5400

Sigaud, S.; Goldsmith, C.A.; Zhou, H.; Yang, Z.; Fedulov, A.; Imrich, A.; \& Kobzik, L. (2007). Air pollution particles diminish bacterial clearance in the primed lungs of mice. Toxicology and Applied Pharmacology, (August, 1, 2007).Vol. 223, No. 1, pp. 1-9. ISSN: 1096-0333

Song, J. W, Hong, S. B, Lim, C.M, Koh, Y. \& Kim, D. S. (2011). Acute exacerbation of idiopathic pulmonary fibrosis: incidence, risk factors and outcome. European Respiratory Journal, Vol. 37, No.2, (February 2011) pp. 356-363, ISSN: 0903-1936

Spaan, S.; Schinkel, J.; Wouters, I.M.; Preller, L.; Tielemans, E.; Nij, E.T.; \& Heederik, D. (2008). Variability in endotoxin exposure levels and consequences for exposure assessment. Annals of Occupational Hygiene, Vol.52, No.5 (July 2008) pp. 303-316. ISSN:0003-4878

Strand, V, Rak, S, Svartengren, M. \& Bylin, G. (1997). Nitrogen dioxide exposure enhances asthmatic reaction to inhaled allergen in subjects with asthma. American Journal of Respiratory and Critical Care Medicine, Vol.155, No. 3, (March 1997), pp 881 -887, ISSN 1073-449XWinterton, DL.; Kaufman, J, Keener CV, Quigley, S, Farin, FM.; Williams PV. \& Koenid, JQ. (2001). Genetic Polymorphism as a Biomarkers of Sensitivity to Inhaled Sulfur Dioxide in Subjects with Asthma. (2001). Annals of Allergy Asthma $\mathcal{E}$ Immunology, Vol.86, No. 2, (February 2001), pp 232-238, ISSN 1073-449X 
Tamagawa, E.; Bai, N.; Morimot, K.; Gray, C.; Mui, T.; Yatera, K.; Zhang, X.; Xing, L.; Laher, I.; Sin, D.D.; Man, S.F.; \& van Eeden, S.F. (2008). Particulate matter exposure induces persistent lung inflammation and endothelial dysfunction. American Journal of Physiology-Lung Cellular and Molecular Physiology. (July, 2008) Vol. 295, No. 1, pp. L79-L85. ISSN:1040-0605

Tamir, S. \& Tannenbaum, S.R. (1996). The Role of Nitric Oxide (NO.) In the Carcinogenic Process. Biochimica et Biophysica Acta. Vol.1288, No.2, (October 1996), pp. F31-F36, ISSN 0304-419X

Torres-Duque, C.; Maldonado, D.; Perez-Padilla, R.; Ezzati, M.; \& Viegi, G. (2008). Biomass fuels and respiratory diseases: a review of the evidence. Proceedings of the American Thoracic Society, Vol. 5, No. 5 (August, 2008) pp. 577-590, ISSN:1546-3222

Tozer, G.M.; Prise, V.E.; \& Chaplin, D.J. (1997). Inhibition of Nitric Oxide Synthase Induces a Selective Reduction in Tumor Blood Flow That is Reversible with L-arginine. Cancer Research, Vol. 57, (March 1997), pp.948-955, ISSN: 0008-5472

United Nations Scientific Committee on the Effects of Atomic Radiation (UNSCEAR). (2000). Sources and Effects of Ionizing Radiation. New York: United Nations. Available from http://www.unscear.org/unscear/publications/2000_1.html

van Eeden, S.F.; Tan, W.C.; Suwa, T.; Mukae, H.; Terashima, T.; Fujii, T.; Oui, D.; Vincent, R.; Hogg, J.C. (2001). Cytokines involved in the systemic inflammatory response induced by exposure to particulate matter air pollutants (PM(10). American Journal of Respiratory and Critical Care Medicine (September, 1, 2001) Vol. 164, No. 5, pp.826830. ISSN: $1535-4970$

Vineis, P. \& Husgafvel-Pursiainen, K. (2005). Air Pollution and Cancer: Biomarker Studies in Human Populations. Carcinogenesis, Vol.26, No.11, (November 2005), pp.1846-1855, ISSN 0143-3334

Wang, L. \& Pinkerton KE. (2008). Detrimental Effects of Tobacco Smoke Exposure During Development on Postnatal Lung Function and Asthma. Birth Defects Research Part C: Embryo Today, Vol.84, No.1, (March 2008), pp. 54-60, ISSN 1542-975X

Wegesser, T.C. \& Last, J.A. (2009) Mouse lung inflammation after instillation of particulate matter collected from a working dairy barn. Toxicology and Applied Pharmacology, Vol. 236, No. 3 (March, 2009) pp. 348-357. ISSN:0041-008X

Westergren-Thorsson, G.; Larsen, K.; Nihlberg, K.; Andersson-Sjoland, A.; Hallgren, O.; Marko-Varga, G. \& Bjermer, L. (2010). Pathological airway remodeling in inflammation. The Clinical Respiratory Journal, Vol.4, No.1 suppl, (May 2010), pp. 18, ISSN: 1752-6981

Wink, DA.; Darbyshire, JF.; Nims, RW.; Saavedra, JE. \& Ford, PC. (1993). Reactions of the Bioregulatory Agent Nitric Oxide in Oxygenated Aqueous Media: Determination of the Kinetics for Oxidation and Nitrosation by Intermediates Generated in the NO/O2 Reaction. Chemical Research Toxicology, Vol. 6, (Jan-Feb 1993), pp.23-7, ISSN 0893-228X

Yang, W. \& Omaye, S.T. (2009). Air Pollutants, Oxidative Stress and Human Health. Mutation Research/ Genetic Toxicology and Environm Mutagenesis, Vol.674, No.1-2, (March 2009), pp. 45-54, ISSN 1383-5718

Zuurbier, M.; Hoek, G.; Oldenwening, M.; Meliefste, K.; van den Hazel, P., \& Brunekreef, B. (2011). Respiratory Effects of Commuters' Exposure to Air Pollution in Traffic. Epidemiology. Vol. 22, No.2, (March 2011), pp. 219-27, ISSN: 1044-3983 


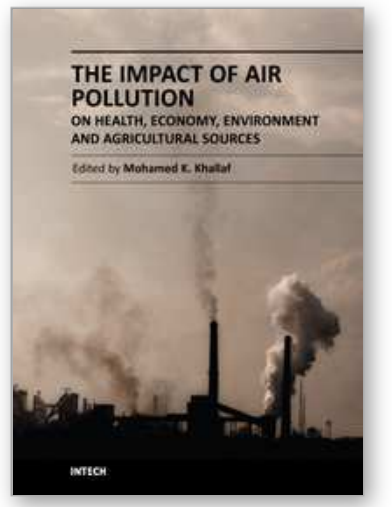

\section{The Impact of Air Pollution on Health, Economy, Environment and Agricultural Sources}

Edited by Dr. Mohamed Khallaf

ISBN 978-953-307-528-0

Hard cover, 444 pages

Publisher InTech

Published online 26, September, 2011

Published in print edition September, 2011

This book aims to strengthen the knowledge base dealing with Air Pollution. The book consists of 21 chapters dealing with Air Pollution and its effects in the fields of Health, Environment, Economy and Agricultural Sources. It is divided into four sections. The first one deals with effect of air pollution on health and human body organs. The second section includes the Impact of air pollution on plants and agricultural sources and methods of resistance. The third section includes environmental changes, geographic and climatic conditions due to air pollution. The fourth section includes case studies concerning of the impact of air pollution in the economy and development goals, such as, indoor air pollution in México, indoor air pollution and millennium development goals in Bangladesh, epidemiologic and economic impact of natural gas on indoor air pollution in Colombia and economic growth and air pollution in Iran during development programs. In this book the authors explain the definition of air pollution, the most important pollutants and their different sources and effects on humans and various fields of life. The authors offer different solutions to the problems resulting from air pollution.

\section{How to reference}

In order to correctly reference this scholarly work, feel free to copy and paste the following:

Fortoul, T.I., Rojas-Lemus, M., Rodriguez-Lara V., Cano-Gutierrez, G., Gonzalez-Villalva, A., Ustarroz-Cano, M., Garcia-Pelaez, I., Lopez-Valdez, N., Falcon-Rodriguez C.I., Silva-Martinez, J., Gonzalez-Rendon, E.S., Montaño, L.F., Cano-Gutierrez, B., Bizarro-Nevares P., Colin Barenque L. (2011). Air Pollution and Its Effects in the Respiratory System, The Impact of Air Pollution on Health, Economy, Environment and Agricultural Sources, Dr. Mohamed Khallaf (Ed.), ISBN: 978-953-307-528-0, InTech, Available from:

http://www.intechopen.com/books/the-impact-of-air-pollution-on-health-economy-environment-andagricultural-sources/air-pollution-and-its-effects-in-the-respiratory-system

\section{INTECH}

open science | open minds

\section{InTech Europe}

University Campus STeP Ri

Slavka Krautzeka 83/A

51000 Rijeka, Croatia

Phone: +385 (51) 770447

Fax: +385 (51) 686166

\section{InTech China}

Unit 405, Office Block, Hotel Equatorial Shanghai

No.65, Yan An Road (West), Shanghai, 200040, China 中国上海市延安西路65号上海国际贵都大饭店办公楼405单元

Phone: +86-21-62489820

Fax: +86-21-62489821 
www.intechopen.com 
(C) 2011 The Author(s). Licensee IntechOpen. This chapter is distributed under the terms of the Creative Commons Attribution-NonCommercialShareAlike-3.0 License, which permits use, distribution and reproduction for non-commercial purposes, provided the original is properly cited and derivative works building on this content are distributed under the same license. 